\title{
Therapeutic Effects of Punica granatum (Pomegranate): An Updated Review of Clinical Trials
}

\author{
Samira Eghbali, ${ }^{1}$ Sayyedeh Fatemeh Askari, ${ }^{2,3}$ Razieh Avan ${ }^{4}{ }^{4}$ \\ and Amirhossein Sahebkar (D) ${ }^{5,6,7}$ \\ ${ }^{1}$ Department of Pharmacognosy, School of Pharmacy, Birjand University of Medical Sciences, Birjand, Iran \\ ${ }^{2}$ Cardiovascular Diseases Research Center, Birjand University of Medical Sciences, Birjand, Iran \\ ${ }^{3}$ Department of Phytopharmaceuticals (Traditional Pharmacy), School of Pharmacy, Birjand University of Medical Sciences, \\ Birjand, Iran \\ ${ }^{4}$ Department of Clinical Pharmacy, Medical Toxicology and Drug Abuse Research Center (MTDRC), School of Pharmacy, \\ Birjand University of Medical Sciences, Birjand, Iran \\ ${ }^{5}$ Applied Biomedical Research Center, Mashhad University of Medical Sciences, Mashhad, Iran \\ ${ }^{6}$ Biotechnology Research Center, Pharmaceutical Technology Institute, Mashhad University of Medical Sciences, Mashhad, Iran \\ ${ }^{7}$ School of Pharmacy, Mashhad University of Medical Sciences, Mashhad, Iran \\ Correspondence should be addressed to Razieh Avan; avanr91@gmail.com
}

Received 14 July 2021; Revised 2 October 2021; Accepted 11 October 2021; Published 16 November 2021

Academic Editor: Eric Gumpricht

Copyright ( $\odot 2021$ Samira Eghbali et al. This is an open access article distributed under the Creative Commons Attribution License, which permits unrestricted use, distribution, and reproduction in any medium, provided the original work is properly cited.

\begin{abstract}
Punica granatum L. belongs to the Punicaceae family which is distributed around the world. Different parts of pomegranate like seed, peel, juice, and leaves are rich in potential bioactive compounds. These plants have found application in traditional medicine such as in treatment of gastrointestinal, cardiovascular, and endocrine diseases, among others. The present review aimed to summarize the current research on the traditional and scientific applications of P. granatum with regard to the phytochemical content and clinical applications that may be useful for future drug development. Information about $P$. granatum was obtained from local classic herbal literature and electronic databases, such as PubMed, Scopus, and ScienceDirect. Several phytochemical constituents including polyphenolics, flavonoids, anthocyanosides, alkaloids, lignans, and triterpenes have been reported from the plant. Randomized clinical trials have provided evidence as to the pharmacological activities of pomegranate in several diseases including diabetes, cardiovascular disease, oral cavity disorders, endocrine disorders, and cancer. The present review has provided an insight into the traditional applications of the plants, and some of them have been validated by scientific evidence, particularly their applications as treatment of cardiovascular and endocrine diseases.
\end{abstract}

\section{Introduction}

1.1. Punica granatum L. (Pomegranate). Punica granatum L. (pomegranate) is a well-known member of Punicaceae family, which comprises two species, Punica granatum (indigenous to Mediterranean regions and Iran) and Punica protopunica (endogenous to Socotra islands). It is widely cultivated throughout Central Asia, the Himalayas, Middle East, American Southwest, and Mediterranean area and is believed to originate from Iran and Afghanistan [1]. The pomegranate tree is a long-living tree that can typically grow up to 12 to 16 feet and live over 200 years. The leaves are glossy and the flowers are red, white, large, or variegated and have tubular calyxes which finally become the fruit. The pomegranate fruit is grenade-shaped with a deep red, leathery skin and crown-shaped calyx. The seeds are surrounded by a small amount of tart and red juice and are separated via white, membranous pericarp [2].

1.2. Applications of Pomegranate. Diet is the principal point among various lifestyle modification factors in traditional Persian medicine, i.e., before using the medication; the first choice is food consumption [3]. The nutritional properties of 
pomegranate have been studied in numerous studies, so it could be a good candidate for food additives and preservatives because of antioxidant and antimicrobial activity, having pectin and fiber. Moreover, waste materials (peels) would be a natural option for food packaging because of plasticizing, strengthening, and elongation activity besides its specific color [4-6]. Pomegranate has been used in traditional medicine for the treatment of diarrhoea, dysentery, hemorrhoids, intestinal parasites, sore throat, diabetes, epistaxis, and vaginal itching and is believed to be tonic for the heart $[7,8]$. In addition, it has recently been used in treatment of numerous diseases including diabetes [9], Alzheimer's disease [10], cancer $[11,12]$, arthritis [13], male infertility [14], obesity [15], and cardiovascular disorders [16]. Many traditional effects of medicinal plants have been proven in modern studies $[17,18]$, so they can be considered as a source for designing new drug formulations. Currently, the COVID-19 pandemic is considered a global public health concern. There is no particular therapy against COVID19. Several clinical and preclinical studies are currently performed to investigate a gold-standard therapy with high possible efficacy and low adverse effect [19, 20]. Pomegranate is recognized as the primary source of principal ingredients, including flavonoids, magnesium, potassium, and iron. It also has antioxidant components, alpha-linolenic acid (omega 3), linoleic acid (omega 6), and oleic acid (omega 9) [21]. In vitro, the aqueous extract of pomegranate peels showed inhibition of COVID19 virus replication [22]. It seems that consumption of pomegranate juice $(\mathrm{PJ})$ can be applied for prophylactic and therapeutic approaches against COVID-19 [21]. At present, one RCT is aiming to evaluate the efficacy of PJ on inflammatory parameters, C-reactive protein (CRP), interleukin 6 (IL-6), erythrocyte sedimentation rate (ESR), and complete blood count (CBC) in mild to moderate COVID-19 patients (IRCT20150711023153N2) [23]. Further clinical studies must be performed to evaluate the effect of pomegranate in the current COVID9 pandemic. In the present study, we investigated the clinical application of pomegranate in the treatment and prevention of different diseases.

\section{Chemistry of $P$. granatum Fruit}

2.1. Polyphenols. The main classes of polyphenols identified in pomegranate are hydrolysable tannins including gallotannins, ellagitannins, gallagyl esters, hydroxycinnamic acids, and hydroxybenzoic acids. The major compound of ellagitannins is punicalagin (2,3-hexahydroxydiphenoyl-4,6 gallagylglucoside) which is mainly found in pericarp, bark, flowers, and seeds isolated by preparative HPLC [24]. In addition to punicalagin and its isomers, pomegranate contains punicalin $\mathrm{A}$ and $\mathrm{B}$ and pedunculagin isomers identified by MS and/or NMR. Gallic acid, ellagic acid, caffeic acid, chlorogenic acid, p-coumaric acid, aglycone, and ferulic acid have also been isolated from pomegranate by HPLC and NMR methods [25-27]. Figure 1 shows the main polyphenolic compounds from pomegranate.
2.2. Anthocyanosides. Anthocyanoside is another primary component present in the flower and fruit and is responsible for the red color of arils (Figure 2). Cyanidin-3-glucoside, cyanidin-3,5-diglucoside, cyanidin 3-rutinoside, cyanidinpentoside, delfinidin-3,5-diglucoside, delfinidin-3-glucoside, pelargonidin-3-glucoside, and pelargonidin-3,5diglucoside are the major anthocyanins detected in the arils, fruit, juice, and flowers elucidated by HPLC and NMR $[8,28]$.

2.3. Other Components. Pomegranate leaves and pericarp contain flavonols and flavones such as catechin, epicatechin, gallocatechin, kaempferol, quercetin, and apigenin, identified by IR and NMR [29]. Active compounds present in different parts of the pomegranate include alkaloids (e.g., pseudopelletierine, pelletierine, isopelletierine, methylpelletierine, 1-pelletierine, dl-pelletierine, and methylisopelletierines) identified by GLC-MS [30] and organic acids (e.g., citric acid, L-malic acid, oxalic acid, ascorbic acid, quinic acid, fumaric acid, tartaric acid, and succinic acid) elucidated by NMR and UHPLC-MS [31].

Lignans (e.g., furofuran, dibenzylbutyrolactone, and dibenzylbutane), minerals (e.g., $\mathrm{Ca}, \mathrm{P}, \mathrm{K}, \mathrm{N}, \mathrm{Mg}$, and $\mathrm{Na}$ ), ursane, oleanane triterpenes (e.g., triterpenic acids), and steroids are other active components isolated from pomegranate identified by LC-MS, HPLC-DAD, and GC-MS [32-35]. The main flavonoid and alkaloid compounds in pomegranate are shown in Figure 3.

\section{Research Method}

We conducted literature research in electronic databases (PubMed, Scopus, and ScienceDirect) to extract clinical studies on Punica granatum or pomegranate with no time limitation. The included search words were "Punica granatum," "Pomegranate," "Clinical trial," "Clinical study," "Blind," or "Volunteer."

\section{Clinical Studies on Different Diseases}

Because of multiple pharmacological activities, pomegranate has been investigated by several clinical studies in a large variety of medical disorders. Different pomegranate activities include anti-inflammatory, antioxidant, and anticancer. Summary of clinical trials using Punica granatum (pomegranate) in different diseases is illustrated in Tables 1-4 and Figure 4 .

\subsection{Diabetes}

4.1.1. Fasting Blood Glucose. In animal studies, polyphenol and antioxidant rich fruits such as pomegranate have shown to stimulate beta cells to secrete insulin [82]. Several human studies have also evaluated the antidiabetic effects of pomegranate. The effect of pomegranate juice (PJ) in diabetic patients in reducing fasting blood glucose (FBG) may be associated with punicic acid, methanolic seed, and pomegranate peel extracts. The underlying mechanism 


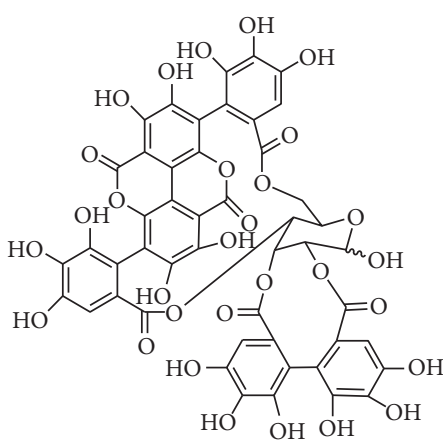

punicalagin

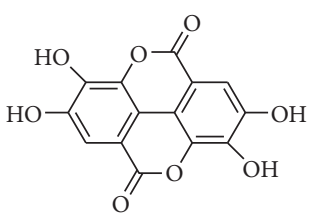

ellagic acid

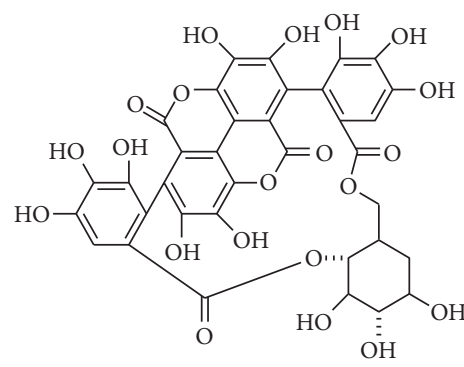

punicalin<smiles>O=C(O)c1cc(O)c(O)c(O)c1</smiles>

pedunculagin<smiles>O=C(O)/C=C/c1ccc(O)c(O)c1</smiles>

caffeic acid<smiles>O=C(/C=C/c1ccc(O)c(O)c1)OC1CC(O)(C(=O)O)CC(O)C1O</smiles>

chlorogenic acid<smiles>O=C(O)/C=C/c1ccc(O)cc1</smiles>

p-coumaric acid<smiles>COc1cc(/C=C/C(=O)O)ccc1O</smiles>

ferulic acid

FIgURE 1: The main phenolic compounds in pomegranate.

responsible for this activity was reducing oxidative stress and lipid peroxidation and inhibiting or activating nuclear factor $\kappa \mathrm{B}$ and peroxisome proliferator-activated receptor $\gamma$ [83]. In one quasi-experimental study on 55 diabetic patients, consumption of concentrated pomegranate juice (CPJ) ( $45 \mathrm{~g} /$ day for 3 month) showed no statistically significant effect on FBG [84]. In another randomized clinical trial (RCT), PJ consumption ( $250 \mathrm{ml} /$ day for 12 weeks) by type 2 diabetic (T2D) patients did not affect FBG or homeostatic model assessment of insulin resistance (HOMA-IR) [85]. Moreover, consumption of CPJ (50 g/day of for 4 weeks) in T2D patients had no statistically significant effect on FBG [86]. Intake of pomegranate seed oil (PSO) $(2000 \mathrm{mg} /$ day for 8 weeks) had no effect on FBG and insulin resistance in 80 diabetic patients [87]. Similarly, wonderful variety pomegranate juice (WPJ) or pomegranate polyphenol extract (WPOMxl) consumption by 30 diabetic patients had no significant effects on FBG or HbA1c level [88]. Conversely, consumption of PSO ( $1 \mathrm{~g} /$ TID for 8 weeks) in 52 obese T2D patients significantly reduced FBG $(p=0.008)$, but insulin, HbA1C, HOMA-IR, and HOMA- $\beta$ did not show any significant changes [89]. Also, fresh PJ consumption $(1.5 \mathrm{ml} / \mathrm{kg})$ in 85 diabetic patients revealed significant reduction in FBG and insulin resistance and increased $\beta$-cell function $(p<0.05)$. This hypoglycemic effect was correlated with baseline FBG levels, as patients with lower FBG levels showed better hypoglycemic response $(p<0.05)$ [90]. In a randomized, double-blind, placebo-controlled trial on 40 patients with diabetes and myocardial infarction, administration of pomegranate extract of whole fruit (PEWF) (300 mg/BID for one month) significantly reduced FBG, postprandial glucose, and HbA1C levels $(p<0.05)$ [82]. In another study, consumption of PJ ( $200 \mathrm{ml} /$ day for 6 weeks) by 50 T2D patients significantly reduced FBG $(p<0.001)$ [91]. Overall, the hypoglycemic effect of PJ or other compounds is limited due to the type of crop, harvest method, dosage, bioavailability, and duration of treatment.

4.1.2. Oxidative Stress. One of the important factors in the pathogenesis of cardiovascular events in diabetic patients is hyperglycemia-induced oxidative stress. Several studies have shown the beneficial role of pomegranate on reducing oxidative stress and lipid peroxidation through direct neutralization of reactive oxygen species (ROS), upregulating antioxidant enzymes, and inhibition or activation of transcription factors such as nuclear factor $\kappa \mathrm{B}(\mathrm{NF}-\kappa \mathrm{B})$ or peroxisome proliferator-activated receptor $\gamma(\operatorname{PPAR} \gamma)$. Various ingredients in pomegranate (e.g., punicalagin, ellagic, gallic, oleanolic, ursolic, and uallic acids) have antidiabetic effects. Also, antioxidant polyphenols including tannins and anthocyanins in the juice sugar fraction could be effective in T2D patients [83]. The antioxidant effects of polyphenol components found in green tea extract, pomegranate extract, and ascorbic acid were studied in uncomplicated T2D patients. Plasma malondialdehyde (MDA), a by-product of lipid peroxidation, was significantly decreased in the study group compared to placebo group $(p<0.001)$. 
<smiles>OCC1OC(Oc2cc3c(O)cc(O)cc3[o+]c2-c2ccc(O)c(O)c2)C(O)C(O)C1O</smiles>

cyanidin-3-glucoside<smiles>OCC1OC(Oc2cc3c(O)cc(O)cc3[o+]c2-c2cc(O)c(O)c(O)c2)C(O)C(O)C1O</smiles>

cyanidin-3,5-diglucoside<smiles></smiles>

delfinidin-3-glucoside<smiles></smiles>

delfinidin-3,5-diglucoside<smiles>OCC1OC(Oc2cc3c(OC4OC(CO)C(O)C(O)C4O)cc(O)cc3[o+]c2-c2ccc(O)cc2)C(O)C(O)C1O</smiles>

pelargonidin-3-glucoside<smiles></smiles>

cyanidin 3-rutinoside<smiles>OCC1OC(Oc2cc3c(O)cc(O)cc3[o+]c2-c2ccc(O)cc2)C(O)C(O)C1O</smiles>

pelargonidin-3,5-diglucoside

FIgURE 2: The main anthocyanoside compounds in pomegranate<smiles>O=c1c(O)c(-c2ccc(O)cc2)oc2cc(O)cc(O)c12</smiles><smiles>Oc1cc(O)c2c(c1)O[C@H](c1cc(O)c(O)c(O)c1)C(O)C2</smiles>

gallocatechin<smiles>Oc1cc(O)c2c(c1)O[C@H](c1ccc(O)c(O)c1)[C@H](O)C2</smiles>

kaempferol<smiles></smiles>

quercetin<smiles>O=c1cc(-c2ccc(O)cc2)oc2cc(O)cc(O)c12</smiles>

apigenin<smiles>CC(=O)CC1CCCCN1</smiles>

pelletierine<smiles>CC(=O)CC1CCCCN1</smiles>

isopelletierine

Figure 3: The main flavonoid and alkaloid compounds in pomegranate.

Total glutathione (GSH) and antioxidant capacity (AOC) as markers of increased antioxidant potency were increased in the study group $(p<0.001)$ [92]. A pilot study investigated the antioxidant effects of pomegranate polyphenols in T2D patients. Consumption of pomegranate polyphenols (2 capsules/day of for 4 weeks) significantly reduced lipid 
TABle 1: Summary of clinical trials using Punica granatum (pomegranate) in endocrine disorders.

\begin{tabular}{|c|c|c|c|c|c|c|}
\hline Disease & Treatment & $\begin{array}{c}\text { No. of } \\
\text { patients }\end{array}$ & Study design & Dosage/duration & Outcomes & References \\
\hline $\begin{array}{l}\text { Erectile } \\
\text { dysfunction }\end{array}$ & $\begin{array}{l}\text { (i) PJ } \\
\text { (ii) Placebo juice }\end{array}$ & 61 & $\begin{array}{l}\text { Double-blind, } \\
\text { RCT }\end{array}$ & $\begin{array}{l}8 \text { ounces daily/two } \\
4 \text {-week treatment } \\
\text { periods separated } \\
\text { by a } 2 \text {-week } \\
\text { washout }\end{array}$ & $\begin{array}{l}\text { Improvement of GAQ } \\
\text { scores. }\end{array}$ & {$[36]$} \\
\hline $\begin{array}{l}\text { Idiopathic central } \\
\text { precocious puberty }\end{array}$ & $\begin{array}{l}\text { (i) Pomegranate extract } \\
\text { juice }+ \text { GnRH analog } \\
\text { (ii) Placebo }+ \text { GnRH analog }\end{array}$ & 225 & $\begin{array}{l}\text { Double-blind, } \\
\text { RCT }\end{array}$ & $\begin{array}{l}100 \mathrm{ml} \text { daily } / 3 \\
\text { months }\end{array}$ & $\begin{array}{l}\text { Improvement of bone } \\
\text { age, growth velocity and } \\
\text { height standard } \\
\text { deviation score. }\end{array}$ & {$[37]$} \\
\hline $\begin{array}{l}\text { Males with poor } \\
\text { semen quality }\end{array}$ & $\begin{array}{l}\text { (i) Tablets containing extract } \\
\text { of pomegranate fruit and } \\
\text { freeze-dried rhizome of } \\
\text { greater galangal } \\
\text { (iii) Placebo tablets }\end{array}$ & 66 & $\begin{array}{l}\text { Double-blind, } \\
\text { RCT }\end{array}$ & $\begin{array}{c}4 \text { tablets with } \\
\text { extract of } \\
\text { P. granatum and } 4 \\
\text { tablets with } \\
\text { A. galanga daily/3 } \\
\text { months }\end{array}$ & $\begin{array}{l}\text { Increase in the total } \\
\text { number of motile } \\
\text { spermatozoa in plant } \\
\text { extracts versus placebo } \\
\quad(p=0.026)\end{array}$ & {$[38]$} \\
\hline $\begin{array}{l}\text { Non-alcoholic fatty } \\
\text { liver disease }\end{array}$ & $\begin{array}{l}\text { (i) PJ } \\
\text { (ii) Orange juice }\end{array}$ & 65 & $\begin{array}{l}\text { Un-blinded, } \\
\text { RCT }\end{array}$ & $\begin{array}{c}250 \mathrm{ml} \text { daily/12 } \\
\text { weeks }\end{array}$ & $\begin{array}{l}\text { Increase in TAC in the } \\
\text { pomegranate group } \\
(p<0.01) .\end{array}$ & {$[39]$} \\
\hline \multicolumn{7}{|c|}{ Gynecology and obstetrics } \\
\hline $\begin{array}{l}\text { Obese } \\
\text { premenopausal } \\
\text { women with non- } \\
\text { alcoholic fatty liver } \\
\text { disease }\end{array}$ & $\begin{array}{l}\text { (i) Xanthigen }{ }^{\mathrm{TM}} \text { (brown } \\
\text { marine algae } \\
\text { fucoxanthin }+ \text { PSO) } \\
\text { (ii) Placebo }\end{array}$ & 151 & $\begin{array}{l}\text { Double-blind, } \\
\text { RCT }\end{array}$ & TDS/16 weeks & $\begin{array}{l}\text { Reduction of weight, } \\
\text { body, and liver fat } \\
\text { content, and } \\
\text { improvement of LFT in } \\
\text { non-diabetic obese } \\
\text { women. }\end{array}$ & {$[40]$} \\
\hline $\begin{array}{l}\text { Heavy menstrual } \\
\text { bleeding of } \\
\text { endometrial origin }\end{array}$ & $\begin{array}{l}\text { (i) } \mathrm{PG} \\
\text { (ii) } \mathrm{TA}\end{array}$ & 76 & $\begin{array}{l}\text { Double-blind, } \\
\text { RCT }\end{array}$ & $\begin{array}{c}500 \mathrm{mg} \text { PG every } \\
6 \mathrm{~h} \text { or } 500 \mathrm{mg} \text { of } \\
\text { TA/5 consecutive } \\
\text { days from the first } \\
\text { day of menses for } 3 \\
\text { cycles }\end{array}$ & $\begin{array}{l}\text { Reduction in the } \\
\text { duration of bleeding and } \\
\text { improvement of QoL } \\
\text { and hematological } \\
\text { assessments. }\end{array}$ & {$[41]$} \\
\hline $\begin{array}{l}\text { Uterine } \\
\text { leiomyoma-related } \\
\text { menorrhagia }\end{array}$ & PG & 19 & $\begin{array}{l}\text { Pilot study } \\
\text { (before/after } \\
\text { style) }\end{array}$ & $\begin{array}{l}5 \mathrm{ml} \text { syrup TDS for } \\
7 \text { days starting } \\
\text { from the onset of } \\
\text { heavy bleeding/ } 3 \\
\text { consecutive } \\
\text { menstrual periods }\end{array}$ & $\begin{array}{l}\text { Reduction of uterine } \\
\text { fibroid size and } \\
\text { leiomyoma bleeding and } \\
\text { improvement of the } \\
\text { QoL. }\end{array}$ & {$[42]$} \\
\hline $\begin{array}{l}\text { Polycystic ovarian } \\
\text { syndrome }\end{array}$ & $\begin{array}{l}\text { (i) SPJ, PJ, and SB } \\
\text { (ii) PB }\end{array}$ & 92 & $\begin{array}{c}\text { Triple- } \\
\text { blinded, RCT }\end{array}$ & $2 \mathrm{~L}$ weekly/8 weeks & $\begin{array}{l}\text { Improvement of insulin } \\
\text { resistance, insulin, } \\
\text { testosterone level, BMI, } \\
\text { weight, and waist } \\
\text { circumference in PCOS. } \\
\text { Improvement of }\end{array}$ & {$[43]$} \\
\hline $\begin{array}{l}\text { Polycystic ovarian } \\
\text { syndrome }\end{array}$ & $\begin{array}{l}\text { (i) } \mathrm{SPJ}, \mathrm{PJ} \text {, and } \mathrm{SB} \\
\text { (ii) } \mathrm{PB}\end{array}$ & 92 & $\begin{array}{c}\text { Triple- } \\
\text { blinded, RCT }\end{array}$ & $\begin{array}{c}300 \mathrm{ml} \text { daily } / 8 \\
\text { weeks }\end{array}$ & $\begin{array}{c}\text { Improvement of } \\
\text { metabolic, oxidative, } \\
\text { inflammatory, and BP } \\
\text { consequences in PCOS. }\end{array}$ & {$[44]$} \\
\hline $\begin{array}{l}\text { Vasomotor } \\
\text { symptoms of } \\
\text { menopause }\end{array}$ & $\begin{array}{l}\text { (1) Black cohosh } \\
\text { (2) Multibotanical (black } \\
\text { cohosh, alfalfa, chaste tree, } \\
\text { dong quai, false unicorn, } \\
\text { licorice, oats, pomegranate, } \\
\text { Siberian ginseng, boron) } \\
\text { (3) Multibotanical plus } \\
\text { dietary soy counseling } \\
\text { (4) Conjugated equine } \\
\text { estrogen with or without } \\
\text { medroxyprogesterone acetate } \\
\text { (5) Placebo }\end{array}$ & 351 & $\begin{array}{l}\text { Double-blind, } \\
\text { RCT }\end{array}$ & $\begin{array}{l}\text { Four capsules } \\
\text { daily/one year }\end{array}$ & $\begin{array}{l}\text { Black cohosh alone or in } \\
\text { combination with } \\
\text { multibotanical product } \\
\text { had little effect on } \\
\text { alleviation of vasomotor } \\
\text { symptoms. }\end{array}$ & {$[45]$} \\
\hline
\end{tabular}


TABle 1: Continued.

\begin{tabular}{|c|c|c|c|c|c|c|}
\hline Disease & Treatment & $\begin{array}{c}\text { No. of } \\
\text { patients }\end{array}$ & Study design & Dosage/duration & Outcomes & References \\
\hline $\begin{array}{l}\text { Menopausal } \\
\text { symptoms }\end{array}$ & $\begin{array}{l}\text { (i) Pomegranate seed oil } \\
\text { (ii) Placebo }\end{array}$ & 81 & $\begin{array}{l}\text { Double-blind, } \\
\text { RCT }\end{array}$ & $\begin{array}{l}\text { Two capsules } \\
\text { daily/12 weeks }\end{array}$ & $\begin{array}{l}\text { PGS in postmenopausal } \\
\text { women could not show } \\
\text { reduction in hot flashes } \\
\text { during a } 12 \text {-week period. }\end{array}$ & {$[46]$} \\
\hline \multicolumn{7}{|c|}{ Rheumatic disorders } \\
\hline \multirow[b]{2}{*}{$\begin{array}{l}\text { Rheumatoid } \\
\text { arthritis }\end{array}$} & POMx & 6 & $\begin{array}{c}\text { Pilot study } \\
\text { (open-labeled) }\end{array}$ & $\begin{array}{l}10 \mathrm{ml} \text { daily/ } \\
12 \text { weeks }\end{array}$ & $\begin{array}{l}\text { Reduction of DAS28 in } \\
\text { RA patients due to its } \\
\text { antioxidant effects. }\end{array}$ & {$[47]$} \\
\hline & $\begin{array}{l}\text { (i) POMx } \\
\text { (ii) Placebo }\end{array}$ & 55 & $\begin{array}{l}\text { Double-blind, } \\
\text { RCT }\end{array}$ & $\begin{array}{c}2 \text { capsules of } \\
250 \mathrm{mg} \text { POMx or } \\
\text { cellulose/8 weeks }\end{array}$ & $\begin{array}{c}\text { Improvement of disease } \\
\text { activity and some blood } \\
\text { biomarkers of } \\
\text { inflammation and } \\
\text { oxidative stress in RA } \\
\text { patients. }\end{array}$ & {$[48]$} \\
\hline \multirow{2}{*}{ Knee osteoarthritis } & $\begin{array}{l}\text { (i) PJ } \\
\text { (ii) Control }\end{array}$ & 38 & Parallel-RCT & $\begin{array}{l}200 \mathrm{ml} \text { daily } / 6 \\
\text { weeks }\end{array}$ & $\begin{array}{l}\text { Improvement of } \\
\text { physical function and } \\
\text { stiffness and antioxidant } \\
\text { properties in patients } \\
\text { with knee OA. }\end{array}$ & {$[49]$} \\
\hline & $\begin{array}{l}\text { (i) Pomegranate peel, hydro } \\
\text { alcoholic extract along with } \\
\text { standard treatment } \\
\text { (ii) Placebo along with } \\
\text { standard treatment }\end{array}$ & 60 & $\begin{array}{l}\text { Double-blind, } \\
\text { RCT }\end{array}$ & $\begin{array}{c}500 \text { mg twice daily/ } \\
8 \text { weeks }\end{array}$ & $\begin{array}{l}\text { Reduction of pain and } \\
\text { improvement of } \\
\text { symptoms in women } \\
\text { with knee OA. }\end{array}$ & {$[50]$} \\
\hline \multicolumn{7}{|c|}{ Renal disorders } \\
\hline Nephrolithiasis & $\begin{array}{l}\text { Pomegranate polyphenol } \\
\text { extract }\end{array}$ & 30 & Pilot study & $\begin{array}{l}1000 \mathrm{mg} \text { daily/90 } \\
\text { days }\end{array}$ & $\begin{array}{l}\text { An increase in PON1 } \\
\text { activity in RSFs with a } \\
\text { trend toward reducing in } \\
\text { SSCaOx. }\end{array}$ & {$[51]$} \\
\hline
\end{tabular}


TABLE 1: Continued.

\begin{tabular}{|c|c|c|c|c|c|c|}
\hline Disease & Treatment & $\begin{array}{l}\text { No. of } \\
\text { patients }\end{array}$ & Study design & Dosage/duration & Outcomes & References \\
\hline \multirow{6}{*}{ Hemodialysis } & $\begin{array}{l}\text { (i) PJ } \\
\text { (ii) Placebo juice }\end{array}$ & 101 & $\begin{array}{l}\text { Double-blind, } \\
\text { RCT }\end{array}$ & $\begin{array}{l}100 \mathrm{ml} \text { three times } \\
\text { a week/one year }\end{array}$ & $\begin{array}{l}\text { Improvement of clinical } \\
\text { outcomes, } \\
\text { cardiovascular risk } \\
\text { factors, innate immunity } \\
\text { and reduced incidence } \\
\text { of hospitalization due to } \\
\text { infections. }\end{array}$ & {$[52]$} \\
\hline & $\begin{array}{l}\text { (i) PJ } \\
\text { (ii) Placebo juice }\end{array}$ & 27 & $\begin{array}{l}\text { Double-blind, } \\
\text { RCT }\end{array}$ & $\begin{array}{l}100 \mathrm{ml} \text { single-dose } \\
\text { during the first } \\
\text { hour of a dialysis } \\
\text { session }\end{array}$ & $\begin{array}{l}\text { Improvement of } \\
\text { oxidative stress and } \\
\text { inflammation induced } \\
\text { by IV iron during } \\
\text { dialysis. }\end{array}$ & [53] \\
\hline & $\begin{array}{l}\text { (i) PJ } \\
\text { (ii) Placebo juice }\end{array}$ & 101 & $\begin{array}{l}\text { Double-blind, } \\
\text { RCT }\end{array}$ & $\begin{array}{l}100 \mathrm{ml} \text { three times } \\
\text { a week/one year }\end{array}$ & $\begin{array}{l}\text { Reduction of systolic } \\
\text { blood pressure and } \\
\text { improved lipid profile. }\end{array}$ & {$[54]$} \\
\hline & $\begin{array}{l}\text { (i) PJ } \\
\text { (ii) Pomegranate extract }\end{array}$ & 24 & $\begin{array}{l}\text { Open-label, } \\
\text { cross-over } \\
\text { clinical trial }\end{array}$ & $\begin{array}{c}100 \mathrm{ml} \text { of juice } \\
\text { before each } \\
\text { dialysis or } \\
1,050 \mathrm{mg} \text { of extract } \\
\text { daily/12 weeks }\end{array}$ & $\begin{array}{c}\text { No effect on } \\
\text { inflammation or } \\
\text { oxidative stress markers, } \\
\text { lipid profile and blood } \\
\text { pressure. }\end{array}$ & {$[55]$} \\
\hline & $\begin{array}{l}\text { (i) POMx } \\
\text { (ii) Placebo }\end{array}$ & 33 & $\begin{array}{l}\text { Double-blind, } \\
\text { RCT }\end{array}$ & $\begin{array}{c}1000 \text { mg capsule } 7 \\
\text { days/week/6 } \\
\text { months }\end{array}$ & $\begin{array}{l}\text { Reduction of blood } \\
\text { pressure and } \\
\text { improvement of } \\
\text { antioxidant activity, but } \\
\text { had no effect on other } \\
\text { markers of } \\
\text { cardiovascular risk, } \\
\text { physical function, or } \\
\text { muscle strength. }\end{array}$ & {$[56]$} \\
\hline & $\begin{array}{l}\text { (i) PJ } \\
\text { (ii) Control: usual care }\end{array}$ & 41 & $\begin{array}{l}\text { Randomized } \\
\text { cross-over trial }\end{array}$ & $\begin{array}{c}100 \mathrm{ml} \text { after } \\
\text { dialysis session } \\
\text { three times a week/ } \\
8 \text { weeks }\end{array}$ & $\begin{array}{l}\text { Improvement of lipid } \\
\text { profile, blood pressure, } \\
\text { oxidative stress, and } \\
\text { inflammation. }\end{array}$ & [57] \\
\hline
\end{tabular}

peroxidation reactive metabolites (MDA and hydroxynonenal (HNE)) in the diabetic group compared to baseline $(p<0.05)$. However, there was no change in oxidized lowdensity lipoprotein cholesterol (LDL-C) level in either groups. These findings revealed that pomegranate polyphenols can decrease lipid peroxidation in diabetic patients with no effect on healthy volunteers [93]. In another study, consumption of CPJ (50 g/day for 4 weeks) in T2D patients increased the serum total antioxidant capacity (TAC) by $75 \%$ (from $381.88 \pm 114.4$ at baseline to $1501 \pm 817$ after administration) [86]. In an RCT, 12-week PJ consumption in T2D patients increased TAC $(p<0.05)$ and decreased MDA levels $(p<0.01)$, compared to the placebo group. But no statistically significant changes were observed in advanced glycated end-product (AGE) markers including carboxy methyl lysine (CML) and pentosidine [94]. In another RCT, consumption of PJ (200 ml/day for 6 weeks) in T2D patients decreased oxidized LDL and anti-oxidized LDL antibodies and increased serum TAC and arylesterase activity of paraoxonase [95]. In another study, PEWF (300 mg/BID for one month) significantly reduced total antioxidant activity, glutathione peroxidase, super-oxide dismutase, and glutathione reductase in patients with diabetes and myocardial infarction $(p<0.05)$ [82]. PJ consumption (50 ml/day for 3 months) significantly reduced lipid peroxides and thiobarbituric acid reactive substances (TBARS) levels, whereas sulfhydryl (SH) groups and paraoxonase 1 (PON1) activity were significantly increased. This study showed antioxidative activity of PJ on serum and on macrophages which could be beneficial for improvement of atherosclerosis in diabetic patients [96].

4.1.3. Inflammation. CPJ consumption (50 g/day for 4 weeks) in T2D patients significantly decreased serum interleukin-6 (IL-6) $(p<0.05)$, but no changes were seen with tumor necrosis factor- $\alpha$ (TNF- $\alpha$ ) and high-sensitivity C-reactive protein (hs-CRP) [86]. In another RCT, PJ consumption ( $250 \mathrm{ml} /$ day for 12 weeks) in T2D patients reduced plasma hs-CRP and IL- 6 levels by $32 \%$ and $30 \%$, respectively $(p<0.05)$. After 12 -week consumption of PJ, the mean plasma IL- 6 and hs-CRP were significantly lower than those of the placebo group $(p<0.05)$ [85]. Also, plasma E-selectin concentration was significantly reduced in the PJ group compared to baseline and placebo group $(p<0.001$ and $p<0.05$, respectively). In the PJ group, NF- $\kappa \mathrm{B}$ p65 in 
TABLe 2: Summary of clinical trials using Punica granatum (pomegranate) in gastrointestinal disorders.

\begin{tabular}{|c|c|c|c|c|c|c|}
\hline Disease & Treatment & $\begin{array}{c}\text { No. of } \\
\text { patients }\end{array}$ & $\begin{array}{l}\text { Study } \\
\text { design }\end{array}$ & $\begin{array}{c}\text { Dosage/ } \\
\text { duration }\end{array}$ & Outcomes & References \\
\hline $\begin{array}{l}\text { Non-pathogenic } \\
\text { anorexia }\end{array}$ & $\begin{array}{l}\text { (i) Appetizer syrup: Kismis } \\
\text { (Vitis vinifera L.), Pipalli (Piper } \\
\text { longum L.), Anar (Punica } \\
\text { granatum L.), Amla (Emblica } \\
\text { officinalis Gaertn), etc. } \\
\text { (ii) Placebo syrup }\end{array}$ & 100 & $\begin{array}{c}\text { Double- } \\
\text { blind, RCT }\end{array}$ & $\begin{array}{c}5 \mathrm{ml} \text { twice daily/ } \\
2 \text { months }\end{array}$ & $\begin{array}{l}\text { Improved abdominal } \\
\text { fullness, general desire to } \\
\text { eat, and satiety in the } \\
\text { intervention group } \\
\text { compared to placebo syrup. }\end{array}$ & [58] \\
\hline $\begin{array}{l}\text { Nausea and } \\
\text { vomiting during } \\
\text { pregnancy }\end{array}$ & $\begin{array}{l}\text { (i) Pomegranate and spearmint } \\
\text { syrup plus vitamin B6 } \\
\text { (ii) B6 tablets }\end{array}$ & 55 & $\begin{array}{l}\text { Un- } \\
\text { blinded, } \\
\text { RCT }\end{array}$ & $\begin{array}{c}\text { Syrup: } 5 \text { cc TDS } \\
\text { Control: } 20 \mathrm{mg} \\
\text { TDS/1 week }\end{array}$ & $\begin{array}{c}\text { Reduction of PUQE- } 24 \\
\text { scores in the syrup group } \\
\text { compared to control group } \\
(p=0.001) .\end{array}$ & [59] \\
\hline \multirow{2}{*}{$\begin{array}{l}\text { Diarrhoea- } \\
\text { predominant } \\
\text { irritable bowel } \\
\text { syndrome }\end{array}$} & $\begin{array}{l}\text { (i) Ayurvedic herbal compound: } \\
\text { Murraya koenigii (curry), } \\
\text { Punica granatum } \\
\text { (pomegranate), and Curcuma } \\
\text { longa (turmeric) } \\
\text { (ii) Placebo }\end{array}$ & 22 & $\begin{array}{l}\text { Double- } \\
\text { blind, } \\
\text { cross-over } \\
\text { RCT }\end{array}$ & $\begin{array}{c}\text { Twice daily } / 4 \\
\text { weeks followed } \\
\text { by a one week } \\
\text { wash out period }\end{array}$ & $\begin{array}{l}\text { No significant improvement } \\
\text { was observed in IBS-D } \\
\text { symptoms compared to } \\
\text { placebo. }\end{array}$ & {$[60]$} \\
\hline & $\begin{array}{l}\text { (i) Traditional Chinese } \\
\text { medicine containing } 11 \text { herbs } \\
\text { including Punica granatum } \\
\text { (ii) Placebo }\end{array}$ & 119 & $\begin{array}{c}\text { Double- } \\
\text { blind, RCT }\end{array}$ & $\begin{array}{l}\text { Twice daily/8 } \\
\text { weeks }\end{array}$ & $\begin{array}{l}\text { No significant difference } \\
\text { was observed in symptom } \\
\text { and QoL scores between two } \\
\text { groups. }\end{array}$ & {$[61]$} \\
\hline $\begin{array}{l}\text { Inflammatory } \\
\text { bowel disease }\end{array}$ & $\begin{array}{l}\text { (i) PJ } \\
\text { (ii) Placebo }\end{array}$ & 36 & $\begin{array}{c}\text { Double- } \\
\text { blind, RCT }\end{array}$ & $\begin{array}{c}125 \mathrm{ml} \text { twice } \\
\text { daily/12 weeks }\end{array}$ & $\begin{array}{c}\text { Reduction of fecal } \\
\text { calprotectin levels in IBD } \\
\text { patients. }\end{array}$ & {$[62]$} \\
\hline \multirow[b]{2}{*}{ Ulcerative colitis } & $\begin{array}{l}\text { (i) Punica granatum peels } \\
\text { aqueous extract syrup } \\
\text { (ii) Placebo syrup }\end{array}$ & 62 & $\begin{array}{c}\text { Double- } \\
\text { blind, RCT }\end{array}$ & $\begin{array}{l}6 \mathrm{~g} \text { of dry peel } \\
\text { daily/4 weeks }\end{array}$ & $\begin{array}{l}\text { Improvement of symptoms } \\
\text { in UC patients. }\end{array}$ & {$[63]$} \\
\hline & $\begin{array}{l}\text { (i) Punica granatum peels } \\
\text { aqueous extract } \\
\text { (ii) Placebo }\end{array}$ & 62 & $\begin{array}{c}\text { Double- } \\
\text { blind, RCT }\end{array}$ & $\begin{array}{l}6 \mathrm{~g} \text { daily/4 } \\
\text { weeks }\end{array}$ & $\begin{array}{l}\text { Patients with hot } \\
\text { temperament showed } \\
\text { higher response to } \\
\text { treatment in comparison to } \\
\text { cold temperament. }\end{array}$ & {$[64]$} \\
\hline
\end{tabular}

peripheral blood mononuclear cell (PBMC) was significantly decreased $(p<0.01)$ and sirtuin 1 (SIRT1) was increased $(p<0.0001)$ compared to placebo group [97]. A pilot study investigated the anti-inflammatory effects of pomegranate polyphenols ( 2 capsules/day for 4 weeks) in T2D patients. Pomegranate polyphenols reduce lipid peroxidation and modulate liver enzymes in patients with T2DM with no effects in healthy controls [93]. Pomegranate has anti-inflammatory properties but studies with a longer duration and bigger sample size are required to further evaluate its effect.

4.1.4. Lipid Profile. The effect of CPJ on lipid profile in T2D patients with hyperlipidemia (cholesterol $\geq 5.2 \mathrm{mmol} / \mathrm{L}$ or triacylglycerol $\geq 2.3 \mathrm{mmol} / \mathrm{L}$ ) was studied. Consumption of CPJ (40 g/day for 8 weeks) remarkably reduced total cholesterol (TC), LDL-C, LDL-C/high-density lipoprotein cholesterol (HDL-C), and TC/HDL-C $(p<0.006, p<0.006$ , $p<0.001$, and $p<0.001$, respectively) with no significant change in triacylglycerol and HDL-C levels [98]. Also, consumption of PJ $(200 \mathrm{ml} /$ day for 6 weeks $)$ by $50 \mathrm{~T} 2 \mathrm{D}$ patients significantly reduced TC and LDL-C $(p<0.001)$, but there was no overall change in triglyceride (TG) and
HDL-C [91]. The effects of polyphenol components (green tea extract, pomegranate extract, and ascorbic acid) on lipid profile were studied in uncomplicated T2D patients. In the study group, the LDL-C level showed statistically significant reduction, whereas the HDL-C level was increased compared to placebo group $(p<0.001$ and $p<0.001$, respectively). Moreover, total plasma GSH and AOC were found to be increased in the intervention compared with the control group [92]. Findings from an RCT revealed that consumption of PJ $(200 \mathrm{ml} /$ day for 6 weeks $)$ in T2D patients significantly decreased TC and LDL-C levels compared to baseline. However, there was no difference in TC, TG, LDLC, and HDL-C levels between the PJ and control groups [99]. In one quasi-experimental study on 55 diabetic patients, consumption of CPJ ( $45 \mathrm{~g} /$ day for 3 month) showed no statistically significant effects on TC and LDL-C [84]. Conversely, CPJ ingestion ( $50 \mathrm{~g} /$ day for 4 weeks) in T2D patients increased TC and HDL-C levels compared to baseline $(p<0.05)$ with no change in serum TG and LDL-C levels [86]. In a randomized double-blind clinical trial on 80 T2D patients, PSO (1000 mg/BID for 8 weeks) had no effect on TC, TG, HDL, and LDL-C [87]. In a recent double-blind, placebo-controlled randomized trial, administration of pomegranate peel extract (PoPEx) capsule (twice a day for 8 
TABle 3: Summary of clinical trials using Punica granatum (pomegranate) in dermatologic disorders.

\begin{tabular}{lllll}
\hline Striae distensae & $\begin{array}{l}\text { Oil-in-water cream containing } \\
\text { Punica granatum seed oil and } \\
\text { Croton lechleri resin extract }\end{array}$ & 20 & $\begin{array}{c}\text { Non-randomized } \\
\text { study }\end{array}$ & $\begin{array}{l}\text { Once daily on } \\
\text { the hip area/6 } \\
\text { weeks }\end{array}$ \\
\hline $\begin{array}{l}\text { Effects on skin } \\
\text { biophysical } \\
\text { parameters }\end{array}$ & $\begin{array}{l}\text { (i) Fixed Polypodium leucotomos/ } \\
\text { pomegranate combination } \\
\left(\text { PPmix }^{\circledR}\right)\end{array}$ & 40 & $\begin{array}{c}\text { Double-blind, } \\
\text { RCT }\end{array}$ & $480 \mathrm{mg}$ daily/3 \\
& $\begin{array}{l}\text { (ii) Polypodium leucotomos } \text { alone } \\
(\text { Fernblock }\end{array}$ & & &
\end{tabular}

(i) Vitaphenol skin cream containing green and white teas,

Facial photodamage mangosteen, and pomegranate 20 extract

Twice daily/60
days

Improvement of striae, dermis

thickness, hydration and elasticity values.

Fixed Polypodium leucotomos/ pomegranate combination improved skin biophysical parameters more than

Polypodium leucotomos alone in adult Caucasians.

$\begin{array}{ll} & \text { (i) Vitaphenol skin cream } \\ & \text { containing green and white teas, } \\ \text { Facial photodamage } & \text { mangosteen, and pomegranate }\end{array}$

$$
\text { (ii) Placebo cream }
$$

RCT

Combination of three antioxidants had an additive efficacy in improvement of facial [67] photodamage.

\begin{tabular}{ll}
\hline & \\
& \\
&
\end{tabular}

(ii) Low-dose POMx

(iii) Placebo

\begin{tabular}{|c|c|c|c|}
\hline $\begin{array}{l}\text { Skin erythema and } \\
\text { melanin }\end{array}$ & $\begin{array}{l}\text { (i) Topical microemulsion } \\
\text { (O/W) of POMx } \\
\text { (ii) Placebo microemulsion } \\
\text { (without extract) }\end{array}$ & 11 & $\begin{array}{l}\text { Single-blinded, } \\
\text { clinical study }\end{array}$ \\
\hline
\end{tabular}

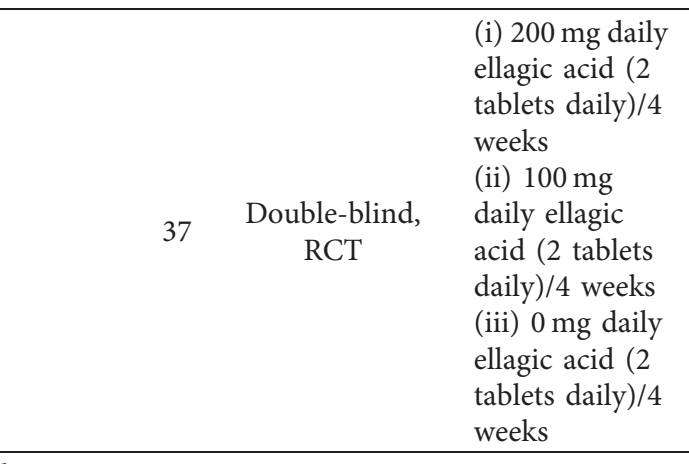

UVB-induced erythema and changes the skin microbiome
(i) POMx
(ii) PJ
(iii) Placebo

At night on
cheeks/12
weeks

(i) $1000 \mathrm{mg}$ daily/12 weeks

(ii) $8 \mathrm{oz}$

daily/12 weeks

(iii) $8 \mathrm{oz}$ daily/12 weeks
Active microemulsion revealed a significant effect on skin erythema and melanin

Orally ellagic acid-rich pomegranate extract had a protective effect against slight sunburn due to UV irradiation.

\begin{tabular}{|c|c|c|c|c|c|c|}
\hline $\begin{array}{l}\text { Diabetic foot } \\
\text { ulceration }\end{array}$ & $\begin{array}{l}\text { (i) Control } \\
\text { (ii) Punica granatum extract } \\
\text { (iii) Propolis extract }\end{array}$ & 60 & $\begin{array}{l}\text { Pretest/posttest } \\
\text { control quasi- } \\
\text { experimental } \\
\text { design }\end{array}$ & - & $\begin{array}{l}\text { Punica granatum and Propolis } \\
\text { are an effective extract to control } \\
\text { the diabetic foot ulceration. }\end{array}$ & {$[71]$} \\
\hline $\begin{array}{l}\text { Non-healing } \\
\text { chronic ulcer }\end{array}$ & $2 \%(w / w)$ PGHF & 1 & Case study & $\begin{array}{l}\text { Once a day/10 } \\
\text { weeks }\end{array}$ & $\begin{array}{l}\text { PGHF (an alternative agent in } \\
\text { wound healing treatment). }\end{array}$ & {$[72]$} \\
\hline Herpes zoster pain & $\begin{array}{l}\text { Hot water extracts of a herbal } \\
\text { formula containing Ganoderma } \\
\text { lucidum and WTMCGEPP } \\
\text { (Wisteria floribunda 0.38, Trapa } \\
\text { natans } 0.38, \text { Myristica agrans } \\
0.38 \text {, Coix lachryma-jobi } 0.75 \text {, } \\
\text { cultivated Ganoderma lucidum } \\
0.75, \text { Elfuinga applanata } 0.38 \text {, } \\
\text { tissue cultured Panax ginseng } 0.3 \text {, } \\
\text { and Punica granatum } 0.38 \text { : } \\
\text { numerals designate dry weight } \\
\text { gram/dose) }\end{array}$ & 5 & Pilot clinical trial & $\begin{array}{l}\text { Several doses } \\
\text { daily }\end{array}$ & Increase in treatment response. & {$[73]$} \\
\hline Dandruff & $\begin{array}{l}\text { Antidandruff shampoo (Zinc- } \\
\text { PCA and piroctone olamine in } \\
\text { combination with Punica } \\
\text { granatum L., Rosmarinus } \\
\text { officinalis L., Matricaria } \\
\text { chamomilla L., Urtica dioica L., } \\
\text { Mentha piperita L., and Salvia } \\
\text { officinalis L. methanolic extracts) }\end{array}$ & 30 & Clinical trial & $\begin{array}{l}3 \text { times a } \\
\text { week } / 2 \text { months }\end{array}$ & $\begin{array}{l}\text { Reduction of dandruff with low } \\
\text { side effects. }\end{array}$ & {$[74]$} \\
\hline
\end{tabular}


TABle 4: Summary of clinical trials using Punica granatum (pomegranate) in other disorders.

\begin{tabular}{|c|c|c|c|c|c|c|}
\hline Disease & Treatment & $\begin{array}{c}\text { No. of } \\
\text { patients }\end{array}$ & Study design & Dosage/duration & Outcomes & References \\
\hline $\begin{array}{l}\text { Chronic obstructive } \\
\text { pulmonary disease } \\
\text { (COPD) }\end{array}$ & $\begin{array}{l}\text { (i) PJ } \\
\text { (ii) Synthetic orange- } \\
\text { flavoured drink }\end{array}$ & 30 & $\begin{array}{l}\text { Double-blind, } \\
\text { RCT }\end{array}$ & $400 \mathrm{ml}$ daily/5 weeks & $\begin{array}{c}\text { No useful effect in } \\
\text { patients with COPD. }\end{array}$ & {$[75]$} \\
\hline $\begin{array}{l}\text { Anxiety during dental } \\
\text { treatment in children }\end{array}$ & $\begin{array}{l}\text { Group I: Pepsi } \\
\text { Cola + } 0.75 \mathrm{mg} / \mathrm{kg} \\
\text { midazolam } \\
\text { Group II: } 10 \% \text { sodium } \\
\text { citrate }+0.75 \mathrm{mg} / \mathrm{kg} \\
\text { midazolam } \\
\text { Group III: } \\
\text { PJ + 0.75 mg } / \mathrm{kg} \\
\text { midazolam } \\
\text { Group IV: grape fruit } \\
\text { juice + } 0.75 \mathrm{mg} / \mathrm{kg} \\
\text { midazolam } \\
\text { Group V: } 0.75 \mathrm{mg} / \mathrm{kg} \\
\text { midazolam orally }\end{array}$ & 75 & $\begin{array}{l}\text { Double-blind, } \\
\text { RCT }\end{array}$ & $\begin{array}{l}\text { Two milliliter each } \\
\text { of compounds } \\
\text { added to midazolam } \\
\text { in equal volumes of } \\
\quad 15 \mathrm{mg} / 3 \mathrm{ml}\end{array}$ & $\begin{array}{l}\text { Increase in the } \\
\text { effectiveness of } \\
\text { sedation with addition } \\
\text { of sodium citrate to } \\
\text { the midazolam. }\end{array}$ & [76] \\
\hline Ischemic stroke & $\begin{array}{l}\text { (i) Pomegranate } \\
\text { polyphenol pills } \\
\text { (ii) Placebo pills }\end{array}$ & 16 & $\begin{array}{l}\text { Double-blind, } \\
\text { RCT }\end{array}$ & $\begin{array}{l}\text { Twice per day/one } \\
\text { week }\end{array}$ & $\begin{array}{l}\text { Improvement of } \\
\text { cognitive and } \\
\text { functional recovery } \\
\text { after stroke. }\end{array}$ & {$[77]$} \\
\hline $\begin{array}{l}\text { Infants with intrauterine } \\
\text { growth restriction }\end{array}$ & $\begin{array}{l}\text { (i) PJ } \\
\text { (ii) Placebo juice }\end{array}$ & 55 & $\begin{array}{l}\text { Double-blind, } \\
\text { RCT }\end{array}$ & $\begin{array}{c}8 \text { oz daily/until } \\
\text { delivery }\end{array}$ & $\begin{array}{l}\text { PJ altered white matter } \\
\text { organization and } \\
\text { functional } \\
\text { connectivity in the } \\
\text { infant brain. }\end{array}$ & {$[78]$} \\
\hline $\begin{array}{l}\text { Memory dysfunction in } \\
\text { heart surgery }\end{array}$ & $\begin{array}{l}\text { (i) POMx pills } \\
\text { (ii) Placebo pills }\end{array}$ & 10 & Pilot study & 2 pills daily/7 weeks & $\begin{array}{c}\text { Improvement of } \\
\text { memory retention skill } \\
\text { after surgery. }\end{array}$ & {$[79]$} \\
\hline Illnesses related to stress & $\begin{array}{l}\text { OCTA@ compound } \\
\text { mixture of eight herbs } \\
\text { including Punica } \\
\text { granatum }\end{array}$ & 17 & $\begin{array}{l}\text { Open-label and } \\
\text { uncontrolled } \\
\text { clinical trial }\end{array}$ & $\begin{array}{l}30 \mathrm{ml} \text { daily } / 3 \\
\text { months }\end{array}$ & $\begin{array}{l}\text { Improvement of } \\
\text { perceptions of stress } \\
\text { and quality of life. }\end{array}$ & {$[80]$} \\
\hline Hypercholesterolemia & $\begin{array}{l}\text { (i) Malas variety of PJ } \\
\text { (ii) Black variety of PJ } \\
\text { (iii) Lovastatin }\end{array}$ & 36 & Clinical study & $200 \mathrm{ml}$ daily/4 weeks & $\begin{array}{c}\text { Reduction of plasma } \\
\text { TC and LDL } \\
(p<0.01)\end{array}$ & {$[81]$} \\
\hline
\end{tabular}

weeks) in $37 \mathrm{~T} 2 \mathrm{D}$ patients significantly reduced plasma levels of TG and LDL-C/HDL-C, increased the HDL-C levels, and enhanced the plasma fatty acid composition [100]. Due to controversial findings obtained from clinical studies, a potential role of pomegranate on improving lipid profile in diabetic patients necessitates more evaluation.

4.1.5. Blood Pressure. PJ is a rich source of soluble polyphenols including anthocyanins and tannins (e.g., ellagitannins (mostly punicalagin), ellagic acid, gallic acid, and catechins). These compounds have anti-inflammatory, antioxidant, anti-hyperlipidemic, and anti-hypertensive properties $[99,101]$. It has been reported that consumption of CPJ ( $50 \mathrm{~g} /$ day for 4 weeks) in T2D patients had no effect on blood pressure [86]. On the contrary, consumption of PJ $(200 \mathrm{ml} /$ day for six weeks) significantly decreased systolic blood pressure (SBP) and diastolic blood pressure (DBP) $(p<0.001$ and $p<0.05$, respectively) in T2D patients. Also, SBP and DBP were lower in the PJ group compared to the control group $(p<0.02$ and $p<0.03$, respectively) [99]. Similarly, PoPEx administration for 8 weeks reduced both SBP and DBP in diabetic patients as was suggested in a recent RCT [100]. The anti-hypertensive effect of pomegranate has been indicated in scant studies, highlighting the need for more extensive results.

4.1.6. Liver Enzymes. Intake of pomegranate polyphenols (2 capsules/day for 4 weeks) increased aspartate aminotransferase (AST) in healthy control group but decreased alanine aminotransferase (ALT) in diabetic patients $(p<0.05)$ [93]. This finding suggests that pomegranate can modulate liver enzymes in diabetic patients.

4.1.7. Obesity. Central obesity is the most common cause of diabetes, cardiovascular disease, and hyperinsulinemia. Pomegranate is a flavonoid-rich fruit with antioxidant properties. The effects of PJ on insulin resistance, hs-CRP, 


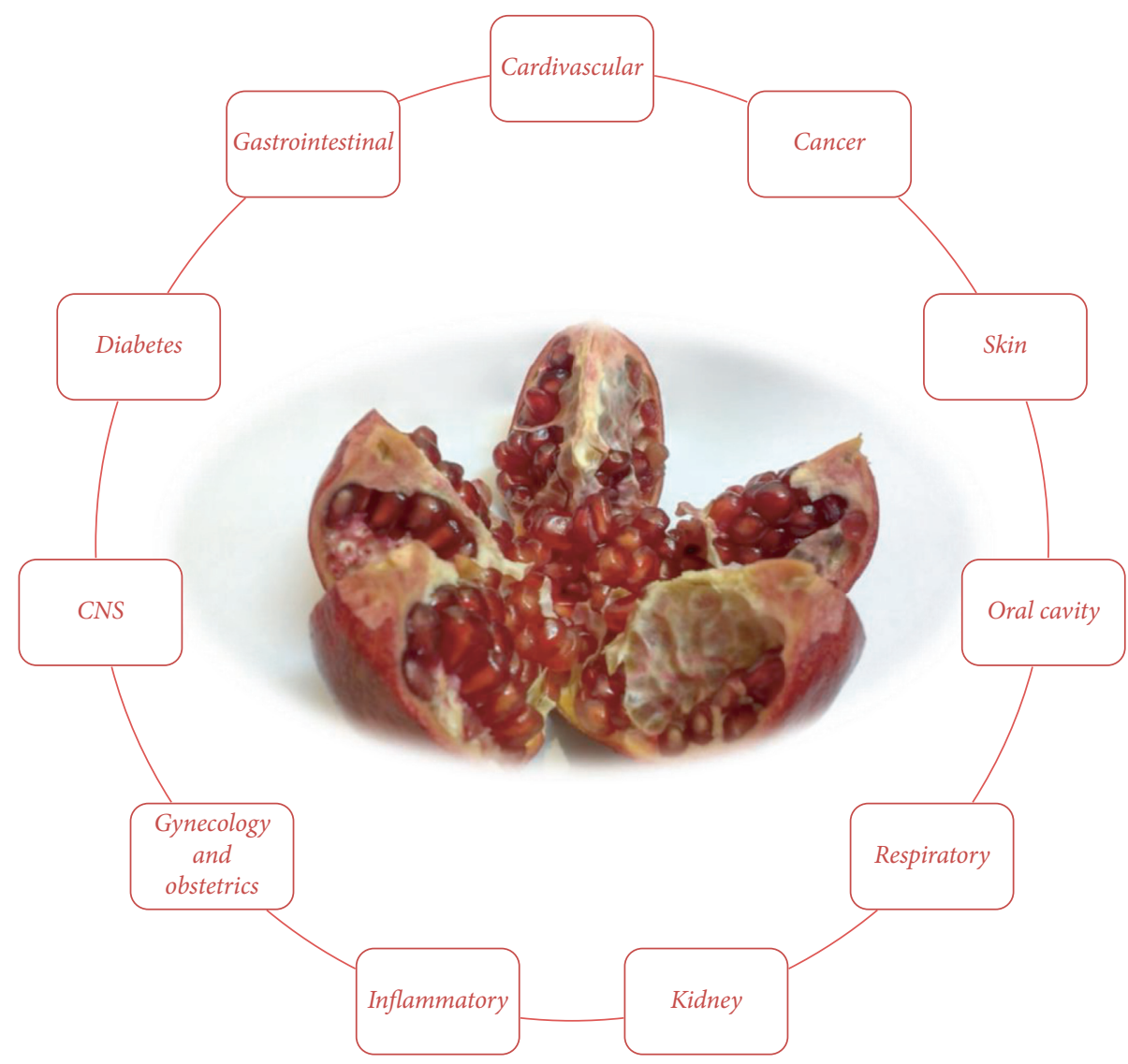

Figure 4: A summary of pomegranate clinical trials in different diseases.

and obesity were studied in an RCT on 50 T2D patients. After 8 weeks, a significant reduction in insulin resistance, body weight, and hip and waist circumference was observed in the study group $(p<0.05, p<0.01, p<0.05$ , and $p<0.05$, respectively), whereas serum glucose, HbAlC, and hs-CRP remained unchanged [102].

4.1.8. Serum Cortisol and Thyroxine. Intake of fresh PJ $(1.5 \mathrm{~mL} / \mathrm{kg})$ on $89 \mathrm{~T} 2 \mathrm{D}$ patients showed remarkable lower levels of serum cortisol one hour after consumption $(p<0.0001)$ which was not related to FBG level or gender [103].

4.1.9. Erythropoietin (EPO). Administration of fresh PJ $(1.5 \mathrm{ml} / \mathrm{kg})$ reduced EPO in diabetic patients (but not in healthy subjects) three hours following consumption and was inversely correlated with FBG, but not with gender or age [104].

4.1.10. Paraoxonase Enzyme Activity. PON1, an HDL-associated enzyme synthesized in the liver, is known to play an important role in prevention of LDL oxidation. Several studies have indicated reduced activity of PON1 in diabetic patients. Consumption of PJ ( $200 \mathrm{ml} /$ day for 6 weeks) by 50 T2D patients significantly increased paraoxonase and arylesterase activity of PON1 $(p<0.001)$ which had positive and negative correlation with HDL-C and FBG levels, respectively [91].

Rock et al. explored the effects of WPJ ( $50 \mathrm{ml} /$ day for 4 weeks) and WPOMxl (5 ml/day for 6 weeks) on PON1 and HDL association in 30 diabetic patients. They concluded that WPJ and WPOMxl delayed the development of atherosclerosis in diabetic patients through PON1 stabilization and increased the association of PON1 with HDL and its catalytic activity [88]. Likewise, PJ consumption (50 ml/day for 4 weeks) by 6 diabetic patients increased the capacity of HDL to bind recombinant paraoxonase-1 [105].

4.2. Cancer. Several in vitro and in vivo studies demonstrated the anticancer properties of pomegranate which inhibits the proliferation of tumor cells and induces their apoptosis. In this section, we review the clinical literature on colorectal, head and neck, and prostate cancers. Intake of pomegranate (2 capsules/day for 6-7 weeks) protected against mucositis- and dermatitis-induced radiotherapy in head and neck cancer [106]. In studies by Nuñez-Sánchez et al., ellagic acid and urolithin derivatives were found in colorectal cancer tissues following consumption of pomegranate extract (900 mg for 15 days) [107]. The same dosage of ellagitannin-containing pomegranate extract successfully modulated gene expression of TYMs, CD44, CDKN, and CTNNB in 35 patients with colorectal cancer [108]. Besides, the expression of microRNAs (a marker for colorectal 
cancer) on the same group of patients and same dosage of pomegranate extract revealed a statistically significant difference between control and treatment group [109]. Another study showed that pomegranate capsule $(900 \mathrm{mg})$ reduced lipopolysaccharide-binding protein (LBP) levels, a marker of endotoxemia, in 57 patients with colorectal cancer [110]. Falsaperla et al. concluded that consumption of pomegranate (a capsule/day containing $180 \mathrm{mg}$ of ellagic tannins) reduced neutropenia and toxicity induced by chemotherapy in hormone-refractory prostate cancer [111]. Urolithin, a metabolite of ellagitannins, was detected in prostate tissue following preoperative administration of PJ (200 ml/day for 3 days) in 63 patients with prostate cancer; however, no changes in the expression of MKi-67, c-Myc, or CDKN1A were observed [112]. In an RCT by Stenner-Liewen et al. on 102 patients with advanced prostate cancer, PJ consumption (500 $\mathrm{ml} /$ day and $250 \mathrm{ml} /$ day for two sequential four weeks) revealed no significant difference between intervention and placebo groups in kinetics and pain scores of PSA serum levels [113].

The efficacy of pomegranate on PSA doubling time was investigated in an RCT on 183 patients undergoing primary therapy for prostate cancer. Patients were assigned to treatment (extract and juice) and placebo groups, and no statistically significant difference was observed in either groups [114]. Paller et al. concluded that consumption of 1 or 2 capsules/day, each one containing $1000 \mathrm{mg}$ polyphenol equal to $8 \mathrm{oz}$ of PJ for 18 months, reduced PSA doubling time in men with repeated prostate cancer [115]. Another study showed that pomegranate extract tablet $(1000 \mathrm{mg}$ containing $600 \mathrm{mg}$ of polyphenol) for four weeks before radical prostatectomy could not lessen 8-hydroxy-20deoxyguanosine (8-OHdG) levels, an oxidative stress biomarker, in 70 men [116]. Although, there are contradictions regarding pomegranate supplementation in cancer treatment, it could be a beneficial anticancer candidate due to components such as ellagic acid. Hence, more RCTs are still needed to determine the underlying molecular mechanism for pomegranate.

\subsection{Cardiovascular Effects}

4.3.1. Hypertension. Juice, whole fruit, seed extract, seed oil, and flowers of $P$. granatum have been used in traditional Persian medicine as anti-hypertensive, cardioprotective (reduction in fibrosis), and anti-hyperlipidemic agents [117]. Anti-hypertensive properties of $P$. granatum are reported in several literatures. In a study by Aviram and Dornfield, PJ consumption ( $50 \mathrm{ml}$ for 2 weeks) in 10 hypertensive patients reduced serum angiotensin-converting enzyme (ACE) levels (by 36\%) and SBP (by 5\%) which were attributed to antioxidative activity of pomegranate [118]. In a single-blind, placebo-controlled clinical trial, intake of PJ (150 ml/day for 2 weeks) in 21 hypertensive subjects reduced SBP, DBP, and vascular endothelial adhesion molecule-1 (VCAM-1) ( $p=0.002,0.038$, and 0.008 , respectively), without any change on flow-mediated dilatation (FMD), intracellular adhesion molecule-1 (ICAM-1), and hs-CRP $(p>0.05)$
[119]. Asgary et al. evaluated the efficacy of PJ intake $(150 \mathrm{ml} /$ day following a 12-hour fasting) on 13 hypertensive patients. A significant reduction in $\operatorname{SBP}(p=0.013)$ and $\mathrm{DBP}$ $(p<0.010)$ was observed, but FMD, CRP, VCAM-1, ICAM1 , and IL-6 levels remained unchanged ( $p=0.172)$ [120]. Reduction of systolic, diastolic, and mean arterial blood pressure was reported in an RCT in which healthy subjects consumed $330 \mathrm{ml} /$ day of PJ for four weeks [121]. Another RCT approved the previous study after drinking $500 \mathrm{ml} /$ day of PJ for four weeks [122]. In short, most studies are inadequate, and we strongly suggest to use pomegranate with caution in hypertensive patients.

4.3.2. Lipid-Lowering Effect. Statins or hydroxy-methylglutaryl-coenzyme A (HMG-CoA) reductase inhibitors are the first-line treatment in hypercholesterolemia. These drugs have numerous side effects including myalgia, myositis, rhabdomyolysis, myopathy, and diabetes mellitus [123]. In an RCT, a supplement containing 12 antioxidant fruits including pomegranate was given to 44 males $(900 \mathrm{mg} / \mathrm{TID}$ for 4 weeks). A reduction in total plasma cholesterol and LDL levels $(p<0.05)$ and an increased level of HDL $(p<0.001)$ were detected in the supplement group following the intervention [124]. In another study, intake of PJ $(200 \mathrm{ml} /$ day) or lovastatin for 4 weeks on 60 patients with hypercholesterolemia generated the same results $(p<0.001)$ [125]. Contrary to previous studies, $400 \mathrm{mg}$ pomegranate seed oil, twice daily for four weeks, does not affect TNF- $\alpha$ levels serum in dyslipidemic patients but could decrease TAG and TAG:HDL-C ratio [126, 127]. Hamoud et al. discovered that consumption of pomegranate extract pill ( $1 \mathrm{~g} /$ day) for two months caused attenuation in LDL-cholesterol levels and improvement in oxidative stress in hypercholesterolemic subjects [128]. Ultimately, as mentioned earlier, more clinical trials with larger sample size are necessary to ascertain the effect of pomegranate on hyperlipidemia.

4.3.3. Metabolic Syndrome. Metabolic syndrome is a wellknown cardiovascular risk factor recognized by dyslipidemia, hyperglycemia, hypertension, abdominal obesity, and proinflammatory states. In a study by Moazzen and Alizadeh, consumption of PJ ( $500 \mathrm{ml}$ for one week) in 32 patients with metabolic syndrome decreased SBP, DBP, and blood hs-CRP but increased TG and very low-density lipoprotein cholesterol (VLDL) due to the high level of fructose [129]. In a clinical study on 23 females with metabolic syndrome who received $300 \mathrm{ml}$ of PJ, the levels of arachidonic acid, lipid peroxidation, TBARS were decreased, whereas monounsaturated fatty acids (MUFA) and saturated fatty acids (SFA) were increased [130]. Many studies reported that consumption of grape $(18 \mathrm{ml} /$ day $)$ and/or PJ ( $240 \mathrm{ml} /$ day $)$ by adolescents with metabolic syndrome for 1 month improved endothelial function and flow-mediated dilation and reduced inflammatory factors including sEselectin, sVCAM, sICAM-1, and IL-6 [131, 132]. Also, consumption of pomegranate concentrate ( $50 \mathrm{~g}$ for 8 weeks) in obese females with metabolic syndrome led to reduction of glucose, 
insulin, and insulin resistance and improved markers of metabolic syndrome and cardiac and respiratory endurance [133]. It is also reported that pomegranate extract reduced markers of platelet activation such as GPIIb-IIIa, p-selectin, and platelet-neutrophil aggregation in 4 subjects with metabolic syndrome [134]. Despite few numbers of patients and short period of treatment, we concluded that consumption of PJ possesses beneficial effects on metabolic syndrome.

4.3.4. Coronary Heart Disease. Ischemic heart disease and oxidative stress following ischemia reperfusion injury cause lipid peroxidation in lipoproteins and arterial macrophages [135]. In a randomized double-blind clinical trial on 15 patients with carotid artery stenosis, consumption of PJ (50 $\mathrm{ml}$ containing $1.5 \mathrm{mmol}$ of total polyphenols for a year) reduced SBP and carotid intima-media thickness and inhibited lipid peroxidation in LDL and serum which was attributed to the antioxidant activity of polyphenols [136]. Also, in another randomized clinical trial on 289 patients with coronary heart disease, treatment with PJ $(240 \mathrm{ml} /$ day for 18 months) lowered the progression of carotid intimamedia thickness in patients with increased levels of oxidative stress [137]. Comparably, the effect of PJ intake $(240 \mathrm{ml} /$ day for 3 months) in 45 patients with coronary heart disease and myocardial ischemia was reported in a randomized, doubleblind, placebo-controlled clinical trial. The results showed an improvement in myocardial ischemia and myocardial perfusion without any effects on blood sugar, blood pressure, weight, and hemoglobin Alc [138]. In a study by Razani et al., a reduction in intensity and duration of angina pectoris and improvement in myocardial ischemia and reperfusion injury in patients with ischemic heart disease were observed following PJ administration [139]. Based on the above data, the antioxidant features of pomegranate juice extract contribute to its robust protective effects against coronary heart disease.

4.3.5. Obesity. Obesity is a common health concern facing our society with major adverse comorbidities including cardiovascular disease, dyslipidemia, hypertension, T2D, respiratory disorders, and cancer. In a clinical study on 38 obese female with dyslipidemia, consumption of $500 \mathrm{mg}$ pomegranate peel extract reduced the levels of serum TC, LDL-C, TG, and hs-CRP and improved serum lipid profile, SBP, and HDL-C [140]. In a randomized clinical trial on 49 overweight-obese subjects with hyperlipidemia, pomegranate extract $(450 \mathrm{mg})$ was administrated in two individual doses (D1 (1 capsule/day) or D2 (4 capsules/day) for 3 weeks). The consumption of pomegranate extract at a dose of D2 $(1.8 \mathrm{~g} /$ day $)$ modulated the gut microbiota, reduced plasma LBP, and thus decreased metabolic endotoxemia and cardiovascular risk [141]. In two pilot clinical studies, the antioxidant activity and safety of pomegranate ellagitanninenriched polyphenol extract were assessed in overweight individuals with increased waist size. There was a significant reduction in TBARS related to cardiovascular disease risk, and no serious adverse effects were observed [142].
Furthermore, a double-blind cross-over design on 14 overweight individuals showed a significant reduction in thiol (SH) levels $0.5(p<0.05), 1(p<0.05)$, and 2 hours $(p<0.01)$ after consumption of high-fat meals plus antioxidant beverage 1 (HFM-AB1; apple, grape, blueberry, and pomegranate juices and grape skin, grape seed, and green tea extracts). Plasma total radical-trapping antioxidant parameter (TRAP) $(2 \mathrm{~h}, p<0.001)$ and urinary ferric reducing antioxidant potency $(0-8 \mathrm{~h}, p<0.01)$ were remarkably increased [143]. In another study, 48 obese and overweight patients received pomegranate extract $(1000 \mathrm{mg})$ or a placebo. After 30 days, the levels of glucose, insulin, LDL-C, TC, IL-6, MDA, and hs-CRP were decreased [144]. Grape/ pomegranate extract dietary supplement had no mitigation effects on 20 adults with abdominal obesity. But it improved insulin sensitivity when consumed 10 hours prior to the administration of oral glucose tolerance test (OGTT) [145]. Also, in a randomized, double-blind clinical trial on 20 obese subjects, treatment with PJ $(120 \mathrm{ml})$ reduced adiposity but did not modify insulin secretion and sensitivity [146]. Park et al. indicated that the intake of pomegranate vinegar ( $700 \mu \mathrm{g}$ ellagic acid/200 mL/day and $1.5 \mathrm{~g}$ acetic acid for 8 weeks) by 78 overweight women led to a reduction in visceral adipose tissue and an increase in AMP-activated protein kinase phosphorylation [147]. In general, consumption of pomegranate juice/extract may prevent obesity and its related disorders.

\subsection{Oral Cavity}

4.4.1. Dental Plaque and Gingivitis. Pomegranate extract acts as an anti-inflammatory compound and free radical scavenger capable of reducing macrophage oxidative stress and lipid peroxidation. It protects against gingivitis through direct antioxidant activity of flavonoid content and indirect effects via increasing free radical scavengers [148]. Several studies have evaluated the effect of pomegranate on oral cavity disorders. In a randomized double-blind controlled trial on 84 patients, pomegranate peel extract lozenge showed significant reduction in gag reflex within dental procedures [149]. The effect of Achyranthes aspera, 0.2\% aqueous chlorhexidine gluconate, and $P$. granatum mouthwash ( $140 \mathrm{ml}$ as a daily rinse after breakfast and before sleeping) on salivary Streptococcus mutans level was assessed in 60 children. After seven days, all of the respective mouthwashes revealed statistically significant decline in S. mutans and plaque index levels $(p<0.01$ and $p<0.05$, $p<0.001$ and $p<0.05$, and $p<0.01$ and $p<0.05$, respectively). Chlorhexidine mouthwash had marginally better results in reducing $S$. mutans levels, and $P$. granatum mouthwash showed more antimicrobial effects than A. aspera [150]. Efficacy of P. granatum, Terminalia chebula, and Vitis vinifera mouthwashes $(10 \mathrm{ml}$ once daily after dinner for 15 days) on salivary S. mutans levels was investigated in a randomized clinical double-blinded study on 80 children subclassified into 4 groups. $P$. granatum revealed maximum reduction in $S$. mutans, but there was no statistically significant difference between all groups [151]. 
Another single-blind randomized controlled trial carried out in 20 healthy individuals also revealed statistically significant reduction in mean plaque of $S$. mutans in both chlorhexidine and $P$. granatum groups at baseline and on the 7 th day follow-up. But there was no statistically significant difference in mean plaque $S$. mutans between two groups at the 7 th day of follow-up [152]. In another randomized, controlled, double-blind clinical trial on 35 students, P. granatum Linn. mouthwash (6.25\%) (twice a day for 14 days) showed a significant reduction in the oral streptococci count [153]. Also, the results of one study on 60 healthy patients indicated that hydroalcoholic extract of $P$. granatum is more effective than both chlorhexidine and distilled water against dental plaque microorganisms (reduction in the colony forming units per milliliter (CFU/ml) by $84 \%, 79 \%$, and $11 \%$, respectively) [154]. These studies showed that $P$. granatum can be used as an alternative to chlorhexidine mouthwash against plaque S. mutans. A gel containing 10\% P. granatum extract was evaluated in a cross-over, double-blind study on 23 volunteers for 2 phases of 21 days each. The results showed no statistically significant difference between placebo and test gel for visible plaque index (VPI) and gingival bleeding index (GBI). This study did not provide antiplaque and antigingivitis effects for P. granatum gel [155]. Another randomized, controlled, double-blind clinical trial conducted on 35 students showed lack of efficacy of $P$. granatum mouthwash (6.25\%) (twice a day for 14 days) for the management of dental biofilm and gingivitis [153]. On the contrary, several studies are available on positive effects of pomegranate mouthwash or gel in reduction of dental plaque and gingival inflammation. In a double-blind randomized controlled trial, the efficacy of pomegranate and chamomile mouth rinse was assessed in 55 patients who suffered from chronic gingivitis for 15 days. The patients were randomly divided into three groups: (1) control group: chlorhexidine $0.12 \%$ solution mouthwash ( $n=18)$; (2) chamomile extract mouthwash $(n=19)$; and (3) pomegranate extract mouthwash $(n=18)$. The chamomile and pomegranate extracts reduced gingival bleeding due to their anti-inflammatory and antimicrobial activities similar to chlorhexidine $0.12 \%$ [156]. Another double-blind, singlecenter, controlled clinical trial on 40 adolescents suggested that pomegranate extract mouthwash (twice daily for 90 days) reduced the mean plaque and gingival index values, as well as total salivary proteins without any adverse effects [157]. A randomized, single-blinded controlled trial was conducted on 32 young adults to examine the effects of pomegranate extract mouthwash (thrice daily for 4 weeks) on gingivitis. It reduced total protein, aspartate aminotransferase activities, alpha-glucosidase activity and increased the antioxidant enzyme ceruloplasmin activities and radical scavenging potency. These data indicated the potential use of pomegranate extracts in toothpastes and mouthwashes [158]. Furthermore, a double-blind clinical trial in 104 patients with mild to moderate gingivitis showed that the effect of pomegranate mouthwash (twice daily for 1 month) was comparable to two commonly used herbal mouthwashes (Persica and Matrica) [159]. In a clinical study, 20 patients with chronic gingivitis used pomegranate or chlorhexidine mouthwash ( $10 \mathrm{ml}$ twice daily for 15 days). A significant improvement in bleeding and gingivitis score was seen in the pomegranate group with no reduction in plaque scores [160]. Also, the effect of P. granatum var. pleniflora mouthwash ( $10 \mathrm{ml}$ every night for 2 weeks) was evaluated in 80 patients with diabetes mellitus and gingivitis. After 2 weeks, modified gingival index in Golnaar mouthwash was more effective than chlorhexidine $(p=0.039)$ [161]. In a controlled, single-blind, randomized study, the effect of herbal extracts including $P$. granatum (pomegranate), Piper nigrum (black pepper), and detoxified copper sulfate versus chlorhexidine was evaluated in 30 patients with chronic periodontitis. Herbal extracts revealed significant reduction in plaque index (PI) but had no effect on sulcus bleeding index (SBI) [162]. Also, the antiplaque effect of pomegranate mouthwash (twice daily for 5 days) was evaluated in 30 periodontally healthy volunteers. The PI significantly increased in all groups (pomegranate, chlorhexidine, and distilled water $)(p<0.01)$ with no statistically significant difference between the pomegranate and chlorhexidine groups. In vitro assay revealed efficacy of pomegranate extract against Aggregatibacter actinomycetemcomitans, Porphyromonas gingivalis, and Prevotella intermedia [163]. Another randomized clinical study in 40 patients with chronic gingivitis also showed that a pomegranate extract-containing gel along with mechanical debridement for 21 days could remarkably ameliorate all the clinical and microbiological indices [164]. In another RCT on 80 healthy subjects, $P$. granatum extract gel decreased the inflammatory markers including IL- $1 \beta$ and IL- 8 serving as an adjunct to mechanical therapy for the treatment of gingivitis [165].

4.4.2. Stomatitis. In several studies, P. granatum gel has been proven to be effective in the management of aphthous stomatitis. In a double-blind clinical trial, 60 patients with mild aphthous stomatitis randomly received $P$. granatum mucoadhesive gel, Triadent oral paste, and placebo (three times a day). The pain elimination time in $P$. granatum group was lower than that in placebo group $(p=0.002)$; however, Triadent and placebo groups had no difference $(p=0.08)$. The duration of wound healing in $P$. granatum group was lower than that in placebo and Triadent groups ( $p=0.001$ and $p=0.04$, respectively) [166]. In another randomized, double-blind, placebo-controlled study on 40 patients with recurrent aphthous stomatitis (RAS), topical $P$. granatum gel $10 \%$ significantly reduced pain elimination time $(p<0.001)$, duration of complete healing $(p<0.001)$, and visual analog scale score $(p<0.001)$, compared to placebo [167]. Furthermore, in a randomized, double-blind study on 56 patients with RAS, the pomegranate peel extract gel (twice daily for one week) showed more efficacy in reducing pain $(p<0.001)$, ulcer size $(p<0.001)$, and duration of ulcer healing $(p<0.001)$ [168]. In a double-blind study on 210 participants with minor RAS, the alcoholic and water extracts of P. granatum var. pleniflora reduced the total time of complete treatment [169]. The antifungal effects of P. granatum Linne gel (three times a day for 15 days) were explored against candidiasis-related denture stomatitis in a 
double-blind study on 60 patients. Yeasts were not detected in $25(83.3 \%)$ patients of miconazole group and $23(76.7 \%)$ patients of pomegranate group [170].

4.4.3. Periodontitis. In a preliminary study, scaling and root planning with subsequent subgingival delivery of Centella asiatica and Punica granatum in the form of biodegradable chips reduced clinical signs of chronic periodontitis in 20 patients [171]. In another study on 15 patients with periodontitis, adjunctive local treatment with $C$. asiatica and $P$. granatum extracts suggested a significant improvement in clinical parameters of chronic periodontitis and IL-1 levels compared to standard supportive periodontal therapy [172].

\section{Conclusion}

Several phytochemical constituents including polyphenolics, flavonoids, anthocyanosides, alkaloids, lignans, and triterpenes have been reported from the plant. The major pharmacological effects of pomegranate reported in randomized clinical trials pertain to diabetes, cardiovascular disease, oral cavity disorders, endocrine disorders, and cancer. The present review has provided an insight into the traditional applications of the plants, and some of them have been validated by scientific evidence, particularly their applications as treatment of cardiovascular and endocrine diseases. Punica granatum and its components have multiple pharmacological effects and clinical applications. Large clinical trials have looked into its therapeutic activities against inflammation, cardiovascular diseases (e.g., hyperlipidemia and hypertension), endocrinopathies (e.g., diabetes), and cancer. However, the underlying molecular mechanism of pomegranate is yet to be determined by more RCTs.

In diabetes, the hypoglycemic effect of the pomegranate juice or other compounds is limited, but its antioxidative effect has been largely discussed in this disorder. As suggested by one study, pomegranate also exerts a modulating effect on liver enzymes in diabetic patients.

Moreover, consumption of pomegranate juice has shown to have preventive roles on obesity, metabolic syndrome, and coronary heart disease (which is believed to be due to its potent antioxidant properties). The beneficial effects of pomegranate mouthwash or gel on periodontitis, gingivitis, and stomatitis are likely related to its anti-inflammatory, antioxidant, and antimicrobial activities. Other benefits of pomegranate suggested by small clinical studies include gastrointestinal system (e.g., anorexia and inflammatory bowel disease (IBD)), central nervous system (e.g., anxiety during dental procedures in children, ischemic stroke, and memory dysfunction in heart surgery), reproductive system (e.g., heavy menstrual bleeding of endometrial origin, uterine leiomyoma-related menorrhagia, polycystic ovarian syndrome (PCOS), and nausea and vomiting during pregnancy), rheumatic disorders (e.g., reactive arthritis (RA) and knee osteoarthritis), dermatologic disorders (e.g., striae distensae, facial photodamage, ultraviolet-induced pigmentation, and skin erythema), and renal diseases, among others. Consequently, further well-designed clinical trials are warranted to establish thorough clinical applications and therapeutic role of pomegranate especially in COVID-19.

\section{Abbreviations}

FBG: $\quad$ Fasting blood glucose

HOMA- Homeostatic model assessment of insulin

IR: resistance

RCT: $\quad$ Randomized clinical trial

T2D: $\quad$ Type 2 diabetes

CPJ: $\quad$ Concentrated pomegranate juice

WPJ: Wonderful variety pomegranate juice

WPOMxl: Pomegranate polyphenol extract

PEWF: $\quad$ Pomegranate extract of whole fruit

ROS: $\quad$ Reactive oxygen species

NF- $\kappa \mathrm{B}: \quad$ Nuclear factor $\kappa \mathrm{B}$

PPAR $\gamma$ : Peroxisome proliferator-activated receptor $\gamma$

MDA: Malondialdehyde

GSH: Total glutathione

AOC: Antioxidant capacity

HNE: Hydroxynonenal

LDL-C: Low-density lipoprotein cholesterol

TAC: $\quad$ Total antioxidant capacity

AGE: $\quad$ Advanced glycated end-product

CML: Carboxy methyl lysine

TBARS: Thiobarbituric acid reactive substances

SH: Sulfhydryl

PON1: $\quad$ Paraoxonase 1

IL-6: $\quad$ Interleukin-6

TNF- $\alpha$ : Tumor necrosis factor- $\alpha$

hs-CRP: High-sensitivity C-reactive protein

PBMC: $\quad$ Peripheral blood mononuclear cell

SIRT1: $\quad$ Sirtuin 1

TC: $\quad$ Total cholesterol

HDL-C: High-density lipoprotein cholesterol

TG: $\quad$ Triglyceride

PoPEx: $\quad$ Pomegranate peel extract

SBP: $\quad$ Systolic blood pressure

DBP: Diastolic blood pressure

AST: Aspartate aminotransferase

ALT: Alanine aminotransferase

EPO: Erythropoietin

ACE: Angiotensin-converting enzyme

FMD: $\quad$ Flow-mediated dilatation

VCAM-1: Vascular endothelial adhesion molecule-1

ICAM-1: Intracellular adhesion molecule-1

HMG- Hydroxy-methyl-glutaryl-coenzyme A

CoA:

VLDL: Very low-density lipoprotein cholesterol

MUFA: Monounsaturated fatty acids

SFA: $\quad$ Saturated fatty acids

HFM- High-fat meals plus antioxidant beverage 1

AB1:

TRAP: Total radical-trapping antioxidant parameter

OGTT: Oral glucose tolerance test

PI: $\quad$ Plaque index

SBI: $\quad$ Sulcus bleeding index 
RAS: $\quad$ Recurrent aphthous stomatitis

WAIS-R: Wechsler Adult Intelligence Scale-Revised

MoCA: Montreal cognitive assessment

IIEF: International index of erectile function

GAQ: Global assessment questionnaires

BDNF: Brain-derived neurotrophic factor

Zinc- $\quad$ Zinc L-pyrrolidone carboxylic acid

PCA:

GnRH: Gonadotropin-releasing hormone

IGF-1: Insulin-like growth factor 1

PHN: $\quad$ Postherpetic neuralgia

PGHF: $\quad$ P. granatum peel ethanolic extract hydrogelbased formulation

PSO: $\quad$ Pomegranate seed oil

LFT: $\quad$ Liver function test

PG: $\quad$ Persian Golnar

TA: $\quad$ Tranexamic acid

QoL: $\quad$ Quality of life

RSFs: $\quad$ Recurrent stone formers

SSCaOx: Supersaturation of calcium oxalate

SPJ: $\quad$ Synbiotic pomegranate juice

SB: $\quad$ Synbiotic beverage

PJ: $\quad$ Pomegranate juice

PB: $\quad$ Placebo beverage

BMI: $\quad$ Body mass index

PCOS: Polycystic ovarian syndrome

BP: $\quad$ Blood pressure

TDS: $\quad$ Three times a day

PUQE-24: 24-hour pregnancy-unique quantification of emesis

IBS-D: Diarrhoea-predominant irritable bowel syndrome

POMx: Pomegranate extract

RA: Rheumatoid arthritis

DAS28: Disease Activity Score 28

OA: $\quad$ Osteoarthritis

IBD: Inflammatory bowel disease

UC: $\quad$ Ulcerative colitis

PGS: $\quad$ Pomegranate seed oil

IV: Intravenous.

\section{Data Availability}

No raw data were used to support this study.

\section{Conflicts of Interest}

The authors declare that they have no conflicts of interest.

\section{References}

[1] E. Shaygannia, M. Bahmani, B. Zamanzad, and M. RafieianKopaei, "A review study on Punica granatum L." Journal of Evidence-Based Complementary \& Alternative Medicine, vol. 21, no. 3, pp. 221-227, 2016.

[2] J. S. Jurenka, "Therapeutic applications of pomegranate (Punica granatum L.): a review," Alternative Medicine Review: A Journal of Clinical Therapeutic, vol. 13, pp. 128-44, 2008.
[3] A. Zargaran, M. Ajdari-Tafti, G. Mosleh, F. Askari, A. Arabzadeh, and A. Ghannadi, "Avicenna's contribution to use meats in cardiovascular diseases," Traditional and Integrative Medicine, vol. 1, pp. 52-53, 2016.

[4] P. Kandylis and E. Kokkinomagoulos, "Food applications and potential health benefits of pomegranate and its derivatives," Foods, vol. 9, no. 2, p. 122, 2020.

[5] K. Ko, Y. Dadmohammadi, and A. Abbaspourrad, "Nutritional and bioactive components of pomegranate waste used in food and cosmetic applications: a review," Foods, vol. 10, no. 3, p. $657,2021$.

[6] O. Panza, A. Conte, and M. A. Del Nobile, "Pomegranate by-products as natural preservative to prolong the shelf life of breaded cod stick," Molecules, vol. 26, no. 8, p. 2385, 2021.

[7] S. F. Askari, A. Mohagheghzadeh, A. Azadi, B. N. Jahromi, M. Tansaz, and P. Badr, "A brief review on vaginal drug delivery in traditional Persian medicine," Traditional and Integrative Medicine, vol. 3, pp. 223-229, 2018.

[8] S. M. Mohammad and H. H. Kashani, "Chemical composition of the plant Punica granatum L. (pomegranate) and its effect on heart and cancer," Journal of Medicinal Plants Research, vol. 6, pp. 5306-5310, 2012.

[9] K. Faddladdeen and A. Ojaimi, "Protective effect of pomegranate (Punica granatum) extract against diabetic changes in adult male rat liver: histological study," Journal of microscopy and ultrastructure, vol. 7, no. 4, p. 165, 2019.

[10] M. S. Almuhayawi, W. S. Ramadan, S. Harakeh et al., "The potential role of pomegranate and its nano-formulations on cerebral neurons in aluminum chloride induced Alzheimer rat model," Saudi Journal of Biological Sciences, vol. 27, no. 7, pp. 1710-1716, 2020.

[11] M. A. Moga, O. G. Dimienescu, A. Bălan et al., "Pharmacological and therapeutic properties of Punica granatum phytochemicals: possible roles in breast cancer," Molecules, vol. 26, no. 4, p. 1054, 2021.

[12] E. Turrini, L. Ferruzzi, and C. Fimognari, "Potential effects of pomegranate polyphenols in cancer prevention and therapy," Oxidative Medicine and Cellular Longevity, vol. 2015, Article ID 938475, 19 pages, 2015.

[13] A. Basu, J. Schell, and R. H. Scofield, "Dietary fruits and arthritis," Food \& Function, vol. 9, no. 1, pp. 70-77, 2018.

[14] A. S. Alshinnawy, W. M. El-Sayed, A. M. Taha, A. A. Sayed, and A. M. Salem, "Astragalus membranaceus and Punica granatum alleviate infertility and kidney dysfunction induced by aging in male rats," Turkish Journal of Biology, vol. 44, no. 4, pp. 166-175, 2020.

[15] M. M. Michicotl-Meneses, M. d. R. Thompson-Bonilla, C. A. Reyes-López et al., "Inflammation markers in adipose tissue and cardiovascular risk reduction by pomegranate juice in obesity induced by a hypercaloric diet in Wistar rats," Nutrients, vol. 13, no. 8, p. 2577, 2021.

[16] D. Wang, C. Özen, I. M. Abu-Reidah et al., "Vasculoprotective effects of pomegranate (Punica granatum L.)," Frontiers in Pharmacology, vol. 9, p. 544, 2018.

[17] S. F. Askari, R. Avan, Z. Tayarani-Najaran, A. Sahebkar, and S. Eghbali, "Iranian Salvia species: a phytochemical and pharmacological update," Phytochemistry, vol. 183, Article ID 112619, 2021.

[18] F. Askari, A. Azadi, B. Namavar-Jahromi, M. Tansaz, A. Mirzapour Nasiri, and A. Mohagheghzadeh, "A comprehensive review about quercus infectoria G. Olivier gall," Research Journal of Pharmacognosy.vol. 7, pp. 69-77, 2020 . 
[19] A. Sahebnasagh, R. Avan, F. Saghafi et al., "Pharmacological treatments of COVID-19," Pharmacological Reports, vol. 72, pp. 1446-1478, 2020.

[20] A. Sahebnasagh, F. Saghafi, R. Avan et al., "The prophylaxis and treatment potential of supplements for COVID-19," European Journal of Pharmacology, vol. 887, Article ID 173530, 2020.

[21] A. Alkhatib, "The use of fresh pomegranate juice in the treatment of COVID-19: clinical case study," PSM Biological Research, vol. 6, pp. 1-4, 2021.

[22] A. f. Mosa and M. a. E. Mohamed, Potential Effect of Pomegranate Peels Extract (Punica granatum) against COVID-19 Virus, Research Square, Durham, NC, USA, 2021.

[23] M. Yousefi, M. Sadriirani, A. PourMahmoudi et al., "Effects of pomegranate juice (Punica granatum) on inflammatory biomarkers and complete blood count in patients with COVID-19: a structured summary of a study protocol for a randomized clinical trial," Trials, vol. 22, 2021.

[24] R.-F. Wang, W.-D. Xie, Z. Zhang et al., "Bioactive compounds from the seeds of Punica granatum (pomegranate)," Journal of Natural Products, vol. 67, no. 12, pp. 2096-2098, 2004.

[25] S. El-Toumy, M. Marzouk, and H. Rauwald, "Ellagi-and gallotannins from Punica granatum heartwood," Die Pharmazie, vol. 56, pp. 823-824, 2001.

[26] S. Wu and L. Tian, "Diverse phytochemicals and bioactivities in the ancient fruit and modern functional food pomegranate (Punica granatum)," Molecules, vol. 22, no. 10, p. 1606, 2017.

[27] V. Vučić, M. Grabež, A. Trchounian, and A. Arsić, "Composition and potential health benefits of pomegranate: a review," Current Pharmaceutical Design, vol. 25, pp. 18171827, 2019.

[28] M. C. P. d. A. Santiago, A. C. M. S. Gouvêa, R. L. d. O. Godoy et al., "Analytical standards production for the analysis of pomegranate anthocyanins by HPLC," Brazilian Journal of Food Technology, vol. 17, no. 1, pp. 51-57, 2014.

[29] P. Bagri, M. Ali, S. Sultana, and V. Aeri, "New flavonoids from Punica granatum flowers," Chemistry of Natural Compounds, vol. 46, no. 2, pp. 201-204, 2010.

[30] H. Neuhöfer, L. Witte, M. Gorunovic, and F.-C. Czygan, "Alkaloids in the bark of Punica granatum L. (pomegranate) from Yugoslavia,” Die Pharmazie, vol. 48, pp. 389-391, 1993.

[31] E. Poyrazoglu, V. Gökmen, and N. Artık, "Organic acids and phenolic compounds in pomegranates (Punica granatum L.) grown in Turkey," Journal of Food Composition and Analysis, vol. 15, no. 5, pp. 567-575, 2002.

[32] U. A. Fischer, A. V. Jaksch, R. Carle, and D. R. Kammerer, "Determination of lignans in edible and nonedible parts of pomegranate (Punica granatum L.) and products derived therefrom, particularly focusing on the quantitation of isolariciresinol using HPLC-DAD-ESI/MSn," Journal of Agricultural and Food Chemistry, vol. 60, no. 1, pp. 283-292, 2012.

[33] S. Wahab, N. Fiki, S. Mostafa, and A. Hassan, "Characterization of certain steroid hormones in Punica granatum L. seeds," Bulletin of Faculty of Pharmacy (Cairo University), vol. 36, 1998.

[34] D. W. Choi, J. Y. Kim, S. H. Choi et al., "Identification of steroid hormones in pomegranate (Punica granatum) using HPLC and GC-mass spectrometry," Food Chemistry, vol. 96, no. 4, pp. 562-571, 2006.

[35] R. Wang, Y. Ding, R. Liu, L. Xiang, and L. Du, "Pomegranate: constituents, bioactivities and pharmacokinetics," Fruit, Vegetable and Cereal Science and Biotechnology, vol. 4, pp. 77-87, 2010.
[36] C. P. Forest, H. Padma-Nathan, and H. R. Liker, "Efficacy and safety of pomegranate juice on improvement of erectile dysfunction in male patients with mild to moderate erectile dysfunction: a randomized, placebo-controlled, doubleblind, crossover study," International Journal of Impotence Research, vol. 19, no. 6, pp. 564-567, 2007.

[37] J. Liu and J. Tang, "Effects of pomegranate extract in supplementing gonadotropin-releasing hormone therapy on idiopathic central precocious puberty in Chinese girls: a randomized, placebo-controlled, double-blind clinical trial," Food \& Function, vol. 8, no. 2, pp. 695-700, 2017.

[38] M. D. K. Fedder, H. B. Jakobsen, I. Giversen, L. P. Christensen, E. T. Parner, and J. Fedder, "An extract of pomegranate fruit and galangal rhizome increases the numbers of motile sperm: a prospective, randomised, controlled, double-blinded trial," PLoS One, vol. 9, no. 10, Article ID e108532, 2014.

[39] G. Ekhlasi, F. Shidfar, S. Agah, S. Merat, and A. F. Hosseini, "Effects of pomegranate and orange juice on antioxidant status in non-alcoholic fatty liver disease patients: a randomized clinical trial," International Journal for Vitamin and Nutrition Research, vol. 85, no. 5-6, pp. 292-298, 2015.

[40] M. Abidov, Z. Ramazanov, R. Seifulla, and S. Grachev, "The effects of Xanthigen in the weight management of obese premenopausal women with non-alcoholic fatty liver disease and normal liver fat," Diabetes, Obesity and Metabolism, vol. 12, no. 1, pp. 72-81, 2010.

[41] A. Goshtasebi, Z. Mazari, S. Behboudi Gandevani, and M. Naseri, "Anti-hemorrhagic activity of Punica granatum L. flower (Persian golnar) against heavy menstrual bleeding of endometrial origin: a double-blind, randomized controlled trial," Medical Journal of the Islamic Republic of Iran, vol. 29, p. 199, 2015.

[42] H. Memarzadeh, T. Eftekhar, M. Tansaz et al., "Evaluation of efficacy of Punica granatum L. (Persian gulnar) on uterine leiomyoma related menorrhagia," International Journal of Biosciences, vol. 6, pp. 18-25, 2015.

[43] Z. Esmaeilinezhad, S. Babajafari, Z. Sohrabi, M.-H. Eskandari, S. Amooee, and R. Barati-Boldaji, "Effect of synbiotic pomegranate juice on glycemic, sex hormone profile and anthropometric indices in PCOS: a randomized, triple blind, controlled trial," Nutrition, Metabolism, and Cardiovascular Diseases, vol. 29, no. 2, pp. 201-208, 2019.

[44] Z. Esmaeilinezhad, R. Barati-Boldaji, N. R. Brett et al., "The effect of synbiotics pomegranate juice on cardiovascular risk factors in PCOS patients: a randomized, triple-blinded, controlled trial," Journal of Endocrinological Investigation, vol. 43, no. 4, pp. 539-548, 2020.

[45] K. M. Newton, S. D. Reed, A. Z. LaCroix, L. C. Grothaus, K. Ehrlich, and J. Guiltinan, "Treatment of vasomotor symptoms of menopause with black cohosh, multibotanicals, soy, hormone therapy, or placebo," Annals of Internal Medicine, vol. 145, no. 12, pp. 869-879, 2006.

[46] L. Auerbach, J. Rakus, C. Bauer et al., "Pomegranate seed oil in women with menopausal symptoms: a prospective randomized, placebo-controlled, double-blinded trial," Menopause, vol. 19, no. 4, pp. 426-432, 2012.

[47] A. Balbir-Gurman, B. Fuhrman, Y. Braun-Moscovici, D. Markovits, and M. Aviram, "Consumption of pomegranate decreases serum oxidative stress and reduces disease activity in patients with active rheumatoid arthritis: a pilot study," The Israel Medical Association Journal, vol. 13, pp. 474-479, 2011.

[48] M. Ghavipour, G. Sotoudeh, E. Tavakoli, K. Mowla, J. Hasanzadeh, and Z. Mazloom, "Pomegranate extract 
alleviates disease activity and some blood biomarkers of inflammation and oxidative stress in rheumatoid arthritis patients," European Journal of Clinical Nutrition, vol. 71, no. 1, pp. 92-96, 2017.

[49] N. Ghoochani, M. Karandish, K. Mowla, M. H. Haghighizadeh, and M. T. Jalali, "The effect of pomegranate juice on clinical signs, matrix metalloproteinases and antioxidant status in patients with knee osteoarthritis," Journal of the Science of Food and Agriculture, vol. 96, no. 13, pp. 4377-4381, 2016.

[50] M. Rafraf, S. Hemmati, M. A. Jafarabadi, A. Moghaddam, and M. K. Haghighian, "Pomegranate (Punica granatum L.) peel hydroalcoholic extract supplementation reduces pain and improves clinical symptoms of knee osteoarthritis: a randomized double-blind placebo controlled study," Iranian Red Crescent Medical Journal, vol. 19, 2017.

[51] C. R. Tracy, J. R. Henning, M. R. Newton, M. Aviram, and M. Bridget Zimmerman, "Oxidative stress and nephrolithiasis: a comparative pilot study evaluating the effect of pomegranate extract on stone risk factors and elevated oxidative stress levels of recurrent stone formers and controls," Urolithiasis, vol. 42, no. 5, pp. 401-408, 2014.

[52] L. Shema-Didi, S. Sela, L. Ore et al., "One year of pomegranate juice intake decreases oxidative stress, inflammation, and incidence of infections in hemodialysis patients: a randomized placebo-controlled trial," Free Radical Biology and Medicine, vol. 53, no. 2, pp. 297-304, 2012.

[53] L. Shema-Didi, B. Kristal, L. Ore, G. Shapiro, R. Geron, and S. Sela, "Pomegranate juice intake attenuates the increase in oxidative stress induced by intravenous iron during hemodialysis," Nutrition Research, vol. 33, no. 6, pp. 442-446, 2013.

[54] L. Shema-Didi, B. Kristal, S. Sela, R. Geron, and L. Ore, "Does pomegranate intake attenuate cardiovascular risk factors in hemodialysis patients?" Nutrition Journal, vol. 13, no. 1, p. 18, 2014.

[55] M. B. Rivara, R. Mehrotra, L. Linke, J. Ruzinski, T. A. Ikizler, and J. Himmelfarb, "A pilot randomized crossover trial assessing the safety and short-term effects of pomegranate supplementation in hemodialysis patients," Journal of Renal Nutrition, vol. 25, no. 1, pp. 40-49, 2015.

[56] P.-T. Wu, P. J. Fitschen, B. M. Kistler et al., "Effects of pomegranate extract supplementation on cardiovascular risk factors and physical function in hemodialysis patients," Journal of Medicinal Food, vol. 18, no. 9, pp. 941-949, 2015.

[57] R. Barati Boldaji, M. Akhlaghi, M. M. Sagheb, and Z. Esmaeilinezhad, "Pomegranate juice improves cardiometabolic risk factors, biomarkers of oxidative stress and inflammation in hemodialysis patients: a randomized crossover trial," Journal of the Science of Food and Agriculture, vol. 100, no. 2, pp. 846-854, 2020.

[58] J. Sastry, P. Tathed, R. K. Rai, and V. Sasibhushan, "Clinical evaluation of efficacy and safety of appetizer syrup as appetite stimulant in children with non-pathogenic anorexia," Indian Journal of Traditional Knowledge, vol. 16, pp. 700-705, 2017.

[59] S. Abdolhosseini, F. Hashem-Dabaghian, R. Mokaberinejad, O. Sadeghpour, and M. Mehrabani, "Effects of pomegranate and spearmint syrup on nausea and vomiting during pregnancy: a randomized controlled clinical trial," Iranian Red Crescent Medical Journal, vol. 19, 2017.

[60] R. Lauche, S. Kumar, J. Hallmann et al., "Efficacy and safety of ayurvedic herbs in diarrhoea-predominant irritable bowel syndrome: a randomised controlled crossover trial," Complementary Therapies in Medicine, vol. 26, pp. 171-177, 2016.
[61] W. K. Leung, J. C. Wu, S. Liang et al., "Treatment of diarrheapredominant irritable bowel syndrome with traditional Chinese herbal medicine: a randomized placebo-controlled trial," American Journal of Gastroenterology, vol. 101, no. 7, pp. 1574-1580, 2006.

[62] E. Scaioli, A. Belluzzi, L. Ricciardiello et al., "Pomegranate juice to reduce fecal calprotectin levels in inflammatory bowel disease patients with a high risk of clinical relapse: study protocol for a randomized controlled trial," Trials, vol. 20, no. 1, p. 327, 2019.

[63] M. Kamali, H. Tavakoli, M. Khodadoost et al., "Efficacy of the Punica granatum peels aqueous extract for symptom management in ulcerative colitis patients. A randomized, placebo-controlled, clinical trial," Complementary Therapies in Clinical Practice, vol. 21, no. 3, pp. 141-146, 2015.

[64] M. Kamali, M. Khodadoost, M. Heydari, H. Tavakoli, H. Hajimehdipoor, and P. Adibi, "The role of syndrome differentiation in the clinical efficacy of Punica granatum on patients with ulcerative colitis," Iranian Red Crescent Medical Journal, vol. 19, 2017.

[65] C. Bogdan, S. Iurian, I. Tomuta, and M. L. Moldovan, "Improvement of skin condition in striae distensae: development, characterization and clinical efficacy of a cosmetic product containing Punica granatum seed oil and Croton lechleri resin extract," Drug Design, Development and Therapy, vol. 11, pp. 521-531, 2017.

[66] E. Emanuele, M. Bertona, and M. Biagi, "Comparative effects of a fixed Polypodium leucotomos/pomegranate combination versus Polypodium leucotomos alone on skin biophysical parameters," Neuroendocrinology Letters, vol. 38, pp. 38-42, 2017.

[67] J. Hsu, G. Skover, and M. P. Goldman, "Evaluating the efficacy in improving facial photodamage with a mixture of topical antioxidants," Journal of Drugs in Dermatology: Journal of Drugs in Dermatology, vol. 6, pp. 1141-1148, 2007.

[68] K. Kasai, M. Yoshimura, T. Koga, M. Arii, and S. Kawasaki, "Effects of oral administration of ellagic acid-rich pomegranate extract on ultraviolet-induced pigmentation in the human skin," Journal of Nutritional Science and Vitaminology, vol. 52, no. 5, pp. 383-388, 2006.

[69] R. Parveen, N. Akhtar, and T. Mahmood, “Topical microemulsion containing Punica granatum extract: its control over skin erythema and melanin in healthy Asian subjects," Advances in Dermatology and Allergology, vol. 6, pp. 351-355, 2014.

[70] S. M. Henning, J. Yang, R. P. Lee et al., "Pomegranate juice and extract consumption increases the resistance to UVBinduced erythema and changes the skin microbiome in healthy women: a randomized controlled trial," Scientific Reports, vol. 9, pp. 14528-14611, 2019.

[71] N. S. H. Al-Irayfawee, D. K. A. A. Al-Biatey, and Z. A. H. AlMubarak, "Effectiveness of punica granatum and propolis: a new dressing method in management of diabetic foot ulceration," Indian Journal of Forensic Medicine \& Toxicology, vol. 13, no. 1, pp. 314-320, 2019.

[72] A. Fleck, P. F. Cabral, F. F. Vieira et al., "Punica granatum L. hydrogel for wound care treatment: from case study to phytomedicine standardization," Molecules, vol. 21, 2016.

[73] Y. Hijikata, A. Yasuhara, and Y. Sahashi, "Effect of an herbal formula containing Ganoderma lucidum on reduction of herpes zoster pain: a pilot clinical trial," The American Journal of Chinese Medicine, vol. 33, no. 4, pp. 517-523, 2005.

[74] M. Sahraie-Rad, A. Izadyari, S. Rakizadeh, and J. Sharifi-Rad, "Preparation of strong antidandruff shampoo using 
medicinal plant extracts: a clinical trial and chronic dandruff treatment," Jundishapur Journal of Natural Pharmaceutical Products, vol. 10, Article ID e21517, 2015.

[75] B. Cerdá, C. Soto, M. D. Albaladejo et al., "Pomegranate juice supplementation in chronic obstructive pulmonary disease: a 5-week randomized, double-blind, placebo-controlled trial," European Journal of Clinical Nutrition, vol. 60, no. 2, pp. 245-253, 2006.

[76] B. Isik, Ö. Baygin, and H. Bodur, "Effect of drinks that are added as flavoring in oral midazolam premedication on sedation success," Pediatric Anesthesia, vol. 18, no. 6, pp. 494-500, 2008.

[77] J. A. Bellone, J. R. Murray, P. Jorge et al., "Pomegranate supplementation improves cognitive and functional recovery following ischemic stroke: a randomized trial," Nutritional Neuroscience, vol. 22, no. 10, pp. 738-743, 2019.

[78] L. G. Matthews, C. D. Smyser, S. Cherkerzian et al., "Maternal pomegranate juice intake and brain structure and function in infants with intrauterine growth restriction: a randomized controlled pilot study," PLoS One, vol. 14, Article ID e0219596, 2019.

[79] S. A. Ropacki, S. M. Patel, and R. E. Hartman, "Pomegranate supplementation protects against memory dysfunction after heart surgery: a pilot study," Evidence-Based Complementary and Alternative Medicine, vol. 2013, Article ID 932401, 8 pages, 2013.

[80] D. Seely and R. Singh, "Adaptogenic potential of a polyherbal natural health product: report on a longitudinal clinical trial," Evidence-Based Complementary and Alternative Medicine, vol. 4, no. 3, pp. 375-380, 2007.

[81] A. Eghdami, M. S. Moghaddasi, and F. Sadeghi, "Determination of antioxidant activity of juice and peel extract of three variety of pomegranate and clinical study," Advances in Environmental Biology, vol. 5, pp. 2282-2288, 2011.

[82] R. Goyal, D. Thawani, D. Thawani, D. Nagtilak, D. Pathania, and D. Jindal, "Antioxidative effect of Punica granatum (pomegranate) on biochemical parameters in patients with diabetes mellitus (type 2) and myocardial infarction: a double blind placebo controlled trial," International Journal of Advanced Research, vol. 4, no. 5, pp. 857-864, 2016.

[83] S. Banihani, S. Swedan, and Z. Alguraan, "Pomegranate and type 2 diabetes," Nutrition Research, vol. 33, no. 5, pp. 341-348, 2013.

[84] A. A. Rashidi, M. F. Jafari, A. Zinsaz, and Z. Sadafi, "Effect of concentrated pomegranate juice consumption on glucose and lipid profile concentrations in type 2 diabetic patients," Zahedan Journal of Research in Medical Sciences, vol. 15, 2013.

[85] G. Sohrab, J. Nasrollahzadeh, H. Zand, Z. Amiri, M. Tohidi, and M. Kimiagar, "Effects of pomegranate juice consumption on inflammatory markers in patients with type 2 diabetes: a randomized, placebo-controlled trial," Journal of Research in Medical Sciences: The Official Journal of Isfahan University of Medical Sciences, vol. 19, pp. 215-20, 2014.

[86] F. Shishehbor, M. Shahi, M. Zarei et al., "Effects of concentrated pomegranate juice on subclinical inflammation and cardiometabolic risk factors for type 2 diabetes: a quasiexperimental study," International Journal of Endocrinology and Metabolism, vol. 14, no. 1, Article ID e33835, 2016.

[87] Z. Faghihimani, P. Mirmiran, G. Sohrab, B. Iraj, and E. Faghihimani, "Effects of pomegranate seed oil on metabolic state of patients with type 2 diabetes mellitus," International Journal of Preventive Medicine, vol. 7, p. 124, 2016.

[88] W. Rock, M. Rosenblat, R. Miller-Lotan, A. P. Levy, M. Elias, and M. Aviram, "Consumption of wonderful variety pomegranate juice and extract by diabetic patients increases paraoxonase 1 association with high-density lipoprotein and stimulates its catalytic activities," Journal of Agricultural and Food Chemistry, vol. 56, no. 18, pp. 8704-8713, 2008.

[89] Y. Khajebishak, L. Payahoo, M. Alivand et al., "Effect of pomegranate seed oil supplementation on the GLUT-4 gene expression and glycemic control in obese people with type 2 diabetes: a randomized controlled clinical trial," Journal of Cellular Physiology, vol. 234, no. 11, pp. 19621-19628, 2019.

[90] S. A. Banihani, S. M. Makahleh, Z. El-Akawi et al., "Fresh pomegranate juice ameliorates insulin resistance, enhances $\beta$-cell function, and decreases fasting serum glucose in type 2 diabetic patients," Nutrition Research, vol. 34, no. 10, pp. 862-867, 2014.

[91] N. Parsaeyan, H. Mozaffari-Khosravi, and M. R. Mozayan, "Effect of pomegranate juice on paraoxonase enzyme activity in patients with type 2 diabetes," Journal of Diabetes and Metabolic Disorders, vol. 11, no. 1, p. 11, 2012.

[92] A. Kutan Fenercioglu, T. Saler, E. Genc, H. Sabuncu, and Y. Altuntas, "The effects of polyphenol-containing antioxidants on oxidative stress and lipid peroxidation in type 2 diabetes mellitus without complications," Journal of Endocrinological Investigation, vol. 33, no. 2, pp. 118-124, 2010.

[93] A. Basu, E. D. Newman, A. L. Bryant, T. J. Lyons, and N. M. Betts, "Pomegranate polyphenols lower lipid peroxidation in adults with type 2 diabetes but have no effects in healthy volunteers: a pilot study," Journal of Nutrition and Metabolism, vol. 2013, Article ID 708381, 7 pages, 2013.

[94] G. Sohrab, P. Angoorani, M. Tohidi, H. Tabibi, M. Kimiagar, and J. Nasrollahzadeh, "Pomegranate (Punica granatum) juice decreases lipid peroxidation, but has no effect on plasma advanced glycated end-products in adults with type 2 diabetes: a randomized double-blind clinical trial," Food \& Nutrition Research, vol. 59, no. 1, Article ID 28551, 2015.

[95] G. Sohrab, S. Ebrahimof, G. Sotoudeh et al., "Effects of pomegranate juice consumption on oxidative stress in patients with type 2 diabetes: a single-blind, randomized clinical trial," International Journal of Food Sciences and Nutrition, vol. 68, no. 2, pp. 249-255, 2017.

[96] M. Rosenblat, T. Hayek, and M. Aviram, "Anti-oxidative effects of pomegranate juice (PJ) consumption by diabetic patients on serum and on macrophages," Atherosclerosis, vol. 187, no. 2, pp. 363-371, 2006.

[97] G. Sohrab, J. Nasrollahzadeh, M. Tohidi, H. Zand, and O. Nikpayam, "Pomegranate juice increases sirtuin1 protein in peripheral blood mononuclear cell from patients with type 2 diabetes: a randomized placebo controlled clinical trial," Metabolic Syndrome and Related Disorders, vol. 16, no. 8, pp. 446-451, 2018.

[98] A. Esmaillzadeh, F. Tahbaz, I. Gaieni, H. Alavi-Majd, and L. Azadbakht, "Concentrated pomegranate juice improves lipid profiles in diabetic patients with hyperlipidemia," Journal of Medicinal Food, vol. 7, no. 3, pp. 305-308, 2004.

[99] G. Sohrab, H. Roshan, S. Ebrahimof, O. Nikpayam, G. Sotoudeh, and F. Siasi, "Effects of pomegranate juice consumption on blood pressure and lipid profile in patients with type 2 diabetes: a single-blind randomized clinical trial," Clinical Nutrition ESPEN, vol. 29, pp. 30-35, 2019.

[100] M. Grabež, R. Škrbić, M. P. Stojiljković et al., "Beneficial effects of pomegranate peel extract on plasma lipid profile, fatty acids levels and blood pressure in patients with diabetes mellitus type-2: a randomized, double-blind, placebo-controlled study," Journal of Functional Foods, vol. 64, Article ID 103692, 2020. 
[101] S. Eghbaliferiz and M. Iranshahi, "Prooxidant activity of polyphenols, flavonoids, anthocyanins and carotenoids: updated review of mechanisms and catalyzing metals," Phytotherapy Research, vol. 30, no. 9, pp. 1379-1391, 2016.

[102] S. Babaeian, M. Ebrahimi-Mameghani, M. Niafar, and S. Sanaii, "The effect of unsweetened pomegranate juice on insulin resistance, high sensitivity c-reactive protein and obesity among type 2 diabetes patients," Journal of Ardabil University of Medical Sciences, vol. 13, pp. 7-15, 2013.

[103] S. A. Banihani, S. M. Makahleh, and Z. J. El-Akawi, "Shortterm effect of fresh pomegranate juice on serum cortisol and thyroxine in patients with type 2 diabetes," Current Molecular Medicine, vol. 20, 2020.

[104] S. A. Banihani, S. M. Shuaibu, B. A. Al-Husein, and S. S. Makahleh, "Fresh pomegranate juice decreases fasting serum erythropoietin in patients with type 2 diabetes," International Journal of Food Science, vol. 2019, Article ID 1269341, 5 pages, 2019.

[105] B. Fuhrman, N. Volkova, and M. Aviram, "Pomegranate juice polyphenols increase recombinant paraoxonase-1 binding to high-density lipoprotein: studies in vitro and in diabetic patients," Nutrition, vol. 26, no. 4, pp. 359-366, 2010.

[106] A. M. Thotambailu, B. S. K. Bhandary, and K. P. Sharmila, "Protective effect of Punica granatum extract in head and neck cancer patients undergoing radiotherapy," Indian Journal of Otolaryngology and Head \& Neck Surgery, vol. 71, no. S1, pp. 318-320, 2019.

[107] M. A. Nuñez-Sánchez, R. García-Villalba, T. Monedero-Saiz et al., "Targeted metabolic profiling of pomegranate polyphenols and urolithins in plasma, urine and colon tissues from colorectal cancer patients," Molecular Nutrition \& Food Research, vol. 58, pp. 1199-1211, 2014.

[108] M. A. Nuñez-Sánchez, A. González-Sarrías, R. García-Villalba et al., "Gene expression changes in colon tissues from colorectal cancer patients following the intake of an ellagitannin-containing pomegranate extract: a randomized clinical trial," The Journal of Nutritional Biochemistry, vol. 42, pp. 126-133, 2017.

[109] M. A. Nuñez-Sánchez, A. Dávalos, A. González-Sarrías et al., "MicroRNAs expression in normal and malignant colon tissues as biomarkers of colorectal cancer and in response to pomegranate extracts consumption: critical issues to discern between modulatory effects and potential artefacts," Molecular Nutrition \& Food Research, vol. 59, pp. 1973-1986, 2015.

[110] A. González-Sarrías, M. A. Núñez-Sánchez, M. A. ÁvilaGálvez et al., "Consumption of pomegranate decreases plasma lipopolysaccharide-binding protein levels, a marker of metabolic endotoxemia, in patients with newly diagnosed colorectal cancer: a randomized controlled clinical trial," Food \& Function, vol. 9, no. 5, pp. 2617-2622, 2018.

[111] M. Falsaperla, G. Morgia, A. Tartarone, R. Ardito, and G. Romano, "Support ellagic acid therapy in patients with hormone refractory prostate cancer (HRPC) on standard chemotherapy using vinorelbine and estramustine phosphate," European Urology, vol. 47, no. 4, pp. 449-455, 2005.

[112] A. González-Sarrías, J. A. Giménez-Bastida, M. T. GarcíaConesa et al., "Occurrence of urolithins, gut microbiota ellagic acid metabolites and proliferation markers expression response in the human prostate gland upon consumption of walnuts and pomegranate juice," Molecular Nutrition \& Food Research, vol. 54, pp. 311-322, 2010.
[113] F. Stenner-Liewen, H. Liewen, R. Cathomas et al., "Daily pomegranate intake has no impact on PSA levels in patients with advanced prostate cancer-results of a phase IIb randomized controlled trial," Journal of Cancer, vol. 4, no. 7, pp. 597-605, 2013.

[114] A. J. Pantuck, C. A. Pettaway, R. Dreicer et al., "A randomized, double-blind, placebo-controlled study of the effects of pomegranate extract on rising PSA levels in men following primary therapy for prostate cancer," Prostate Cancer and Prostatic Diseases, vol. 18, no. 3, pp. 242-248, 2015.

[115] C. J. Paller, X. Ye, P. J. Wozniak et al., "A randomized phase II study of pomegranate extract for men with rising PSA following initial therapy for localized prostate cancer," Prostate Cancer and Prostatic Diseases, vol. 16, no. 1, pp. 50-55, 2013.

[116] S. J. Freedland, M. Carducci, N. Kroeger et al., "A doubleblind, randomized, neoadjuvant study of the tissue effects of POMx pills in men with prostate cancer before radical prostatectomy," Cancer Prevention Research, vol. 6, no. 10, pp. 1120-1127, 2013.

[117] Z. Sobhani, S. R. Nami, S. A. Emami, A. Sahebkar, and B. Javadi, "Medicinal plants targeting cardiovascular diseases in view of Avicenna," Current Pharmaceutical Design, vol. 23, pp. 2428-2443, 2017.

[118] M. Aviram and L. Dornfeld, "Pomegranate juice consumption inhibits serum angiotensin converting enzyme activity and reduces systolic blood pressure," Atherosclerosis, vol. 158, no. 1, pp. 195-198, 2001.

[119] S. Asgary, A. Sahebkar, M. R. Afshani, M. Keshvari, S. Haghjooyjavanmard, and M. Rafieian-Kopaei, "Clinical evaluation of blood pressure lowering, endothelial function improving, hypolipidemic and anti-inflammatory effects of pomegranate juice in hypertensive subjects," Phytotherapy Research, vol. 28, no. 2, pp. 193-199, 2014.

[120] S. Asgary, M. Keshvari, A. Sahebkar, M. Hashemi, and M. Rafieian-Kopaei, "Clinical investigation of the acute effects of pomegranate juice on blood pressure and endothelial function in hypertensive individuals," ARYA Atherosclerosis, vol. 9, pp. 326-31, 2013.

[121] A. Lynn, H. Hamadeh, W. C. Leung, J. M. Russell, and M. E. Barker, "Effects of pomegranate juice supplementation on pulse wave velocity and blood pressure in healthy young and middle-aged men and women," Plant Foods for Human Nutrition, vol. 67, no. 3, pp. 309-314, 2012.

[122] C. Tsang, N. F. Smail, S. Almoosawi, I. Davidson, and E. A. Al-Dujaili, "Intake of polyphenol-rich pomegranate pure juice influences urinary glucocorticoids, blood pressure and homeostasis model assessment of insulin resistance in human volunteers," Journal of Nutritional Science, vol. 1, p. e9, 2012.

[123] P. D. Thompson, G. Panza, A. Zaleski, and B. Taylor, "Statinassociated side effects," Journal of the American College of Cardiology, vol. 67, no. 20, pp. 2395-2410, 2016.

[124] M. Abidov, M. Jimenez Del Rio, A. Ramazanov, O. Kalyuzhin, and I. Chkhikvishvili, "Efficiency of pharmacologically-active antioxidant phytomedicine radical fruits in treatment hypercholesteremia at men," Georgian Medical News, vol. 140, pp. 78-83, 2006.

[125] E. Anoosh, E. Mojtaba, and S. Fatemeh, "Study the effect of juice of two variety of pomegranate on decreasing plasma LDL cholesterol," Procedia-Social and Behavioral Sciences, vol. 2, no. 2, pp. 620-623, 2010.

[126] P. Mirmiran, M. R. Fazeli, G. Asghari, A. Shafiee, and F. Azizi, "Effect of pomegranate seed oil on hyperlipidaemic 
subjects: a double-blind placebo-controlled clinical trial," British Journal of Nutrition, vol. 104, no. 3, pp. 402-406, 2010.

[127] G. Asghari, S. Sheikholeslami, P. Mirmiran et al., "Effect of pomegranate seed oil on serum TNF- $\alpha$ level in dyslipidemic patients," International Journal of Food Sciences and Nutrition, vol. 63, no. 3, pp. 368-371, 2012.

[128] S. Hamoud, T. Hayek, N. Volkova et al., "Pomegranate extract (POMx) decreases the atherogenicity of serum and of human monocyte-derived macrophages (HMDM) in simvastatin-treated hypercholesterolemic patients: a double-blinded, placebo-controlled, randomized, prospective pilot study," Atherosclerosis, vol. 232, no. 1, pp. 204-210, 2014.

[129] H. Moazzen and M. Alizadeh, "Effects of pomegranate juice on cardiovascular risk factors in patients with metabolic syndrome: a double-blinded, randomized crossover controlled trial," Plant Foods for Human Nutrition (Dordrecht, Netherlands), vol. 72, pp. 126-133, 2017.

[130] M. Kojadinovic, A. Arsic, J. Debeljak-Martacic et al., "Pomegranate juice consumption decrease blood lipid peroxidation and level of arachidonic acid in women with metabolic syndrome," Journal of the Science of Food and Agriculture, vol. 97, 2016.

[131] M. Jazi, R. Kelishadi, A. Zakerameli, N. Khavarian, S. Ghatrehsamani, and P. Poursafa, "Acute and long term effects of grape and pomegranate juice consumption on vascular reactivity in pediatric metabolic syndrome," Cardiology in the Young, vol. 20, pp. 73-77, 2010.

[132] R. Kelishadi, S. S. Gidding, M. Hashemi, M. Hashemipour, A. Zakerameli, and P. Poursafa, "Acute and long term effects of grape and pomegranate juice consumption on endothelial dysfunction in pediatric metabolic syndrome," Journal of Research in Medical Sciences: The Official Journal of Isfahan University of Medical Sciences, vol. 16, pp. 245-253, 2011.

[133] F. Sadegh Eghbali, N. Bijeh, and S. R. Attarzadeh Hoseini, "Effect of eight weeks of combined training exercise with and without pomegranate concentrate consumption on metabolic syndrome indexes in obese and overweight middleaged women," The Iranian Journal of Obstetrics, Gynecology and Infertility, vol. 19, pp. 16-24, 2016.

[134] A. Konić-Ristić, T. Srdić-Rajić, N. Kardum et al., "Effects of bioactive-rich extracts of pomegranate, persimmon, nettle, dill, kale and sideritis and isolated bioactives on arachidonic acid induced markers of platelet activation and aggregation," Journal of the Science of Food and Agriculture, vol. 93, pp. 3581-3587, 2013.

[135] S. Eghbaliferiz, F. Farhadi, G. E. Barreto, M. Majeed, and A. Sahebkar, "Effects of curcumin on neurological diseases: focus on astrocytes," Pharmacological Reports, vol. 72, no. 4, pp. 769-782, 2020.

[136] M. Aviram, M. Rosenblat, D. Gaitini et al., "Pomegranate juice consumption for 3 years by patients with carotid artery stenosis reduces common carotid intima-media thickness, blood pressure and LDL oxidation," Clinical Nutrition, vol. 23, no. 3, pp. 423-433, 2004.

[137] M. H. Davidson, K. C. Maki, M. R. Dicklin et al., "Effects of consumption of pomegranate juice on carotid intima-media thickness in men and women at moderate risk for coronary heart disease," The American Journal of Cardiology, vol. 104, no. 7, pp. 936-942, 2009.

[138] M. D. Sumner, M. Elliott-Eller, G. Weidner et al., "Effects of pomegranate juice consumption on myocardial perfusion in patients with coronary heart disease," The American Journal of Cardiology, vol. 96, no. 6, pp. 810-814, 2005.
[139] Z. Razani, M. Dastani, and H. R. Kazerani, "Cardioprotective effects of pomegranate (Punica granatum) juice in patients with ischemic heart disease," Phytotherapy Research, vol. 31, no. 11, pp. 1731-1738, 2017.

[140] M. K. Haghighian, M. Rafraf, A. Moghaddam, S. Hemmati, M. A. Jafarabadi, and B. P. Gargari, "Pomegranate (Punica granatum L.) peel hydro alcoholic extract ameliorates cardiovascular risk factors in obese women with dyslipidemia: a double blind, randomized, placebo controlled pilot study," European Journal of Integrative Medicine, vol. 8, no. 5, pp. 676-682, 2016.

[141] A. González-Sarrías, M. Romo-Vaquero, R. García-Villalba, A. Cortés-Martín, M. V. Selma, and J. C. Espín, "The endotoxemia marker lipopolysaccharide-binding protein is reduced in overweight-obese subjects consuming pomegranate extract by modulating the gut microbiota: a randomized clinical trial," Molecular Nutrition \& Food Research, vol. 62, Article ID 1800160, 2018.

[142] D. Heber, N. P. Seeram, H. Wyatt et al., "Safety and antioxidant activity of a pomegranate ellagitannin-enriched polyphenol dietary supplement in overweight individuals with increased waist size," Journal of Agricultural and Food Chemistry, vol. 55, no. 24, pp. 10050-10054, 2007.

[143] C. Miglio, I. Peluso, A. Raguzzini et al., "Fruit juice drinks prevent endogenous antioxidant response to high-fat meal ingestion," British Journal of Nutrition, vol. 111, no. 2, pp. 294-300, 2014.

[144] B. Hosseini, A. Saedisomeolia, L. G. Wood, M. Yaseri, and S. Tavasoli, "Effects of pomegranate extract supplementation on inflammation in overweight and obese individuals: a randomized controlled clinical trial," Complementary Therapies in Clinical Practice, vol. 22, pp. 44-50, 2016.

[145] I. F. Pérez-Ramírez, E. H. de Diego, M. Riomoros-Arranz, R. Reynoso-Camacho, F. Saura-Calixto, and J. PérezJiménez, "Effects of acute intake of grape/pomegranate pomace dietary supplement on glucose metabolism and oxidative stress in adults with abdominal obesity," International Journal of Food Sciences \& Nutrition, vol. 71, no. 1, pp. 94-105, 2020.

[146] M. González-Ortiz, E. Martínez-Abundis, M. C. EspinelBermúdez, and K. G. Pérez-Rubio, "Effect of pomegranate juice on insulin secretion and sensitivity in patients with obesity," Annals of Nutrition and Metabolism, vol. 58, no. 3, pp. 220-223, 2011.

[147] J. E. Park, J. Y. Kim, J. Kim et al., "Pomegranate vinegar beverage reduces visceral fat accumulation in association with AMPK activation in overweight women: a double-blind, randomized, and placebo-controlled trial," Journal of Functional Foods, vol. 8, pp. 274-281, 2014.

[148] D. Prasad and R. Kunnaiah, "Punica granatum: a review on its potential role in treating periodontal disease," Journal of Indian Society of Periodontology, vol. 18, no. 4, p. 428, 2014.

[149] E. Hekmatian, E. Shadmehr, and G. Asghari, "Effect of pomegranate peel extract lozenge on gag reflex in dental patients," Journal of Isfahan Dental School, vol. 7, pp. 229235, 2011.

[150] A. Bansal, N. Marwah, A. G. Nigam, P. Goenka, and D. Goel, "Effect of Achyranthes aspera, $0.2 \%$ aqueous chlorhexidine gluconate and Punica granatum oral rinse on the levels of salivary Streptococcus mutans in 8 to 12 years old children," The Journal of Contemporary Dental Practice, vol. 16, pp. 903-909, 2015.

[151] P. Mishra, N. Marwah, N. Agarwal, Y. Chaturvedi, and T. Suohu, "Comparison of punica granatum, Terminalia 
chebula, and Vitis vinifera seed extracts used as mouthrinse on salivary Streptococcus mutans levels in children," The Journal of Contemporary Dental Practice, vol. 20, pp. 920927, 2019.

[152] M. Srilekha and P. Jayashri, "Comparing the antimicrobial effectiveness of Punica granatum and chlorhexidine-containing mouthwash: a single-blind randomized clinical trial," Drug Invention Today, vol. 10, 2018.

[153] D. R. de Medeiros Nóbrega, R. L. Santos, R. C. Soares, P. M. Alves, A. C. D. Medeiros, and J. V. Pereira, "A randomized, controlled clinical trial on the clinical and microbiological efficacy of Punica granatum Linn mouthwash," Pesquisa Brasileira em Odontopediatria e Clínica Integrada, vol. 15, 2015.

[154] S. M. S. Menezes, L. N. Cordeiro, and G. S. B. Viana, "Punica granatum (pomegranate) extract is active against dental plaque," Journal of Herbal Pharmacotherapy, vol. 6, no. 2, pp. 79-92, 2006.

[155] A. D. Y. Salgado, J. L. Maia, S. L. d. S. Pereira, T. L. G. d. Lemos, and O. M. d. L. Mota, "Antiplaque and antigingivitis effects of a gel containing Punica granatum Linn extract: a double-blind clinical study in humans," Journal of Applied Oral Science, vol. 14, no. 3, pp. 162-166, 2006.

[156] A. L. A. Batista, R. Diógenes Alves Uchôa Lins, R. de Souza Coelho, D. do Nascimento Barbosa, N. Moura Belém, and F. J. Alves Celestino, "Clinical efficacy analysis of the mouth rinsing with pomegranate and chamomile plant extracts in the gingival bleeding reduction," Complementary Therapies in Clinical Practice, vol. 20, no. 1, pp. 93-98, 2014.

[157] J. C. Deepak and S. R. Samuel, "Effectiveness of pomegranate mouthrinse in reducing bacterial plaque, gingival inflammation and total salivary proteins over a period of 90 days: a double-blind randomized trial," Journal of the International Academy of Periodontology, vol. 20, pp. 110-114, 2018.

[158] R. A. DiSilvestro, D. J. DiSilvestro, and D. J. DiSilvestro, "Pomegranate extract mouth rinsing effects on saliva measures relevant to gingivitis risk," Phytotherapy Research, vol. 23, no. 8, pp. 1123-1127, 2009.

[159] F. Kiany, H. Niknahad, and M. Niknahad, "Assessing the effect of pomegranate fruit seed extract mouthwash on dental plaque and gingival inflammation," Journal of Dental Research and Review, vol. 3, no. 4, p. 117, 2016.

[160] S. Ahuja, V. Dodwad, B. Kukreja, P. Mehra, and P. Kukreja, "A comparative evaluation of efficacy of Punica granatum and chlorhexidine on plaque and gingivitis," Journal of the International Clinical Dental Research Organization, vol. 3, no. 1, p. 29, 2011.

[161] M. Sedigh-Rahimabadi, M. Fani, M. Rostami-chijan, M. M. Zarshenas, and M. Shams, "A traditional mouthwash (Punica granatum var pleniflora) for controlling gingivitis of diabetic patients: a double-blind randomized controlled clinical trial," Journal of Evidence-Based Complementary \& Alternative Medicine, vol. 22, no. 1, pp. 59-67, 2017.

[162] S. Abullais, N. Dani, N. P. Hamiduddin, N. Priyanka, N. Kudyar, and A. Gore, "Efficacy of irrigation with different antimicrobial agents on periodontal health in patients treated for chronic periodontitis: a randomized controlled clinical trial," AYU (An International Quarterly Journal of Research in Ayurveda), vol. 36, no. 4, p. 380, 2015.

[163] S. J. Bhadbhade, A. B. Acharya, S. V. Rodrigues, and S. L. Thakur, "The antiplaque efficacy of pomegranate mouthrinse," Quintessence international (Berlin, Germany: 1985), vol. 42, pp. 29-36, 2011.
[164] C. Somu, S. Ravindra, S. Ajith, and M. Ahamed, "Efficacy of a herbal extract gel in the treatment of gingivitis: a clinical study," Journal of Ayurveda and Integrative Medicine, vol. 3, no. 2, p. 85, 2012.

[165] J. Prakash, V. Bhatnagar, S. Nath, S. Pulikkotil, and V. K. Prajapati, "Effect of punica granatum extract gel on gingival crevicular fluid levels of interleukin-1 $\beta$, interleukin8 and CCL28 levels: randomised controlled clinical trial," Journal of Clinical and Diagnostic Research, vol. 11, 2017.

[166] A. Tavangar, A. Aslani, and N. Nikbakht, "Comparative study of punica granatum gel and triadent oral paste effect on recurrent aphthous stomatitis, a double blind clinical trial," Journal of Dentistry (Shiraz, Iran), vol. 20, pp. 184-189, 2019.

[167] P. Ghalayani, B. Zolfaghary, A. R. Farhad, A. Tavangar, and B. Soleymani, "The efficacy of Punica granatum extract in the management of recurrent aphthous stomatitis," Journal of Research in Pharmacy Practice, vol. 2, pp. 88-92, 2013.

[168] S. Darakhshan, M. Malmir, F. Bagheri et al., "The effects of pomegranate peel extract on recurrent aphthous stomatitis," Current Issues in Pharmacy and Medical Sciences, vol. 32, no. 3, pp. 115-120, 2019.

[169] S. Gavanji, B. Larki, and A. Bakhtari, "The effect of extract of Punica granatum var. pleniflora for treatment of minor recurrent aphthous stomatitis," Integrative Medicine Research, vol. 3, no. 2, pp. 83-90, 2014.

[170] L. César de Souza Vasconcelos, M. C. C. Sampaio, F. C. Sampaio, and J. S. Higino, "Use of Punica granatum as an antifungal agent against candidosis associated with denture stomatitis," Mycoses, vol. 46, no. 5-6, pp. 192-196, 2003.

[171] G. Sastravaha, P. Yotnuengnit, P. Booncong, and P. Sangtherapitikul, "Adjunctive periodontal treatment with Centella asiatica and Punica granatum extracts. A preliminary study," Journal of the International Academy of Periodontology, vol. 5, pp. 106-115, 2003.

[172] G. Sastravaha, G. Gassmann, P. Sangtherapitikul, and W. D. Grimm, "Adjunctive periodontal treatment with Centella asiatica and Punica granatum extracts in supportive periodontal therapy," Journal of the International Academy of Periodontology, vol. 7, pp. 70-79, 2005. 